\title{
AgAuPd/meso- $\mathrm{Co}_{3} \mathrm{O}_{4}:$ High-performance catalysts for methanol oxidation
}

\author{
Jun Yang, Yuxi Liu *, Jiguang Deng, Xingtian Zhao, Kunfeng Zhang, Zhuo Han, Hongxing Dai \# \\ Beijing Key Laboratory for Green Catalysis and Separation, Key Laboratory of Beijing on Regional Air Pollution Control, Key Laboratory of Advanced \\ Functional Materials, Education Ministry of China, Laboratory of Catalysis Chemistry and Nanoscience, Department of Chemistry and Chemical Engineer- \\ ing, College of Environmental and Energy Engineering, Beijing University of Technology, Beijing 100124, China
}

\section{A R T I C L E I N F O}

\section{Article history:}

Received 27 October 2018

Accepted 26 November 2018

Published 5 June 2019

\section{Keywords:}

Volatile organic compound

Mesoporous cobalt oxide

Supported noble metal catalyst

AgAuPd alloy nanoparticle

Methanol oxidation

\begin{abstract}
A B S T R A C T
The meso- $\mathrm{Co}_{3} \mathrm{O}_{4}$ and $\mathrm{Ag}_{x} \mathrm{Au}_{y} \mathrm{Pd} /$ meso- $\mathrm{Co}_{3} \mathrm{O}_{4}$ catalysts were prepared using the KIT-6-templating and polyvinyl alcohol-protected $\mathrm{NaBH}_{4}$ reduction methods, respectively. Various techniques were used to characterize physicochemical properties of these materials. Catalytic performance of the samples was evaluated for methanol combustion. The cubically crystallized $\mathrm{Co}_{3} \mathrm{O}_{4}$ support displayed a three-dimensionally ordered mesoporous structure. The supported noble metal nanoparticles (NPs) possessed a surface area of $115-125 \mathrm{~m}^{2} / \mathrm{g}$, with the noble NPs (average size $=2.8-4.5 \mathrm{~nm}$ ) being uniformly dispersed on the surface of meso- $\mathrm{Co}_{3} \mathrm{O}_{4}$. Among all of the samples, $0.68 \mathrm{wt} \%$

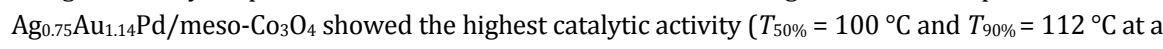
space velocity of $80000 \mathrm{~mL}\left(\mathrm{~g}^{-1} \mathrm{~h}^{-1}\right)$. The partial deactivation of the $0.68 \mathrm{wt} \%$ $\mathrm{Ag}_{0.75} \mathrm{Au}_{1.14} \mathrm{Pd} /$ meso- $\mathrm{CO}_{3} \mathrm{O}_{4}$ sample due to water vapor or carbon dioxide introduction was reversible. It is concluded that the good catalytic performance of $0.68 \mathrm{wt} \% \mathrm{Ag}_{0.75} \mathrm{Au}_{1.14} \mathrm{Pd} / \mathrm{meso}-\mathrm{Co}_{3} \mathrm{O}_{4}$ was associated with its highly dispersed $\mathrm{Ag}_{0.75} \mathrm{Au}_{1.14} \mathrm{Pd}$ alloy NPs, high adsorbed oxygen species concentration, good low-temperature reducibility, and strong interaction between $\mathrm{Ag}_{0.75} \mathrm{Au}_{1.14} \mathrm{Pd}$ alloy NPs and meso- $-\mathrm{Co}_{3} \mathrm{O}_{4}$.
\end{abstract}

(C) 2019, Dalian Institute of Chemical Physics, Chinese Academy of Sciences. Published by Elsevier B.V. All rights reserved.

\section{Introduction}

VOCs are major contributors to ozone and photochemical smog, which lead to air pollution and human being's sickness [1]. Methanol is one of the VOCs and widely used as solvents, fuels for specialized vehicles or feedstock for manufacturing of other value-added chemicals $[2,3]$. Furthermore, methanol is highly toxic and harmful to human health. Hence, it is essential to develop practical and cost-effective methods to control the emission of methanol. Up to now, the most efficient technology for VOC elimination is the catalytic combustion, which pos- sesses a number of advantages, such as high efficiency, low light-off temperature, simple equipment, and no secondary pollution $[4,5]$. The key point is to choose effective catalysts with high performance.

Supported noble metals (especially Pd) have been considered as the most popular catalysts used for VOCs combustion due to their high performance at low temperatures [6,7]. Nevertheless, the presence of moisture can be the adverse factor influencing the activity of a supported noble metal catalyst [8]. Noble metal alloy catalysts were reported to possess activities superior to those of their single-component counterparts, and

\footnotetext{
* Corresponding author. Tel: +86-10-67396118; Fax: +86-10-67391983; E-mail: yxliu@bjut.edu.cn

\# Corresponding author. Tel: +86-10-67396118; Fax: +86-10-67391983; E-mail: hxdai@bjut.edu.cn

This work was supported by the National Natural Science Foundation of China $(21677004,21876006$, and 21622701) and the National High Technology Research and Development Program of China (863 Program, 2015AA034603).

DOI: 10.1016/S1872-2067(18)63205-X | http://www.sciencedirect.com/science/journal/18722067 | Chin. J. Catal., Vol. 40, No. 6, June 2019
} 
the former also displayed better thermal stability and poison-resistant ability than the latter. For example, Wei and coworkers reported that the $\mathrm{AuPd} / 3 \mathrm{DOM}^{-\mathrm{TiO}_{2}}$ [9], $\mathrm{PtRu} / \mathrm{TiO}_{2}$ [10], and $\mathrm{Pd}_{x} \mathrm{Co}_{3-x} \mathrm{O}_{4} / 3 \mathrm{DOM} \mathrm{Ce}_{0.2} \mathrm{Zr}_{0.8} \mathrm{O}_{2}$ [11] catalysts were active for the photocatalytic reduction of $\mathrm{CO}_{2}$ and soot combustion. Calzada et al. [1] found that the $\mathrm{Ru}-\mathrm{Au} / \mathrm{TiO}_{2}$ catalyst performed better than the supported $\mathrm{Ru}$ or $\mathrm{Au}$ counterpart at low temperatures $\left(<50{ }^{\circ} \mathrm{C}\right)$ in the total oxidation of methanol. Wang et al. [12] reported that the $0.96 \mathrm{AuPd}_{1.92} / \mathrm{Co}_{3} \mathrm{O}_{4}$ sample showed a higher catalytic activity for toluene and $o$-xylene oxidation (the temperature required for achieving 90\% conversion of toluene and $o$-xylene was 180 and $187^{\circ} \mathrm{C}$, respectively) than the supported Au or Pd catalyst at a space velocity (SV) of $40000 \mathrm{~mL}\left(\mathrm{~g}^{-1} \mathrm{~h}^{-1}\right)$. The authors assigned the good catalytic activity of $0.96 \mathrm{AuPd}_{1.92} / \mathrm{Co}_{3} \mathrm{O}_{4}$ to the high concentration of adsorbed oxygen species and strong interaction between $\mathrm{Au}-\mathrm{Pd}$ nanoparticles (NPs) and $\mathrm{Co}_{3} \mathrm{O}_{4}$. Xie et al. [13] synthesized a series of the supported Au-Pd catalysts and found that these porous transition-metal oxide-supported Au-Pd NPs showed high activity and good (hydro)thermal stability for toluene or methane combustion. Guo et al. [14] observed better performance for methanol combustion of the $\mathrm{TiO}_{2}$-supported $\mathrm{Pd}-\mathrm{Pt}$ NPs than the supported Pd NPs, a result due to a more amount of adsorbed oxygen species on the former than on the latter. Xie et al. [15] pointed out that the three-dimensionally ordered macroporous (3DOM) $\mathrm{Co}_{3} \mathrm{O}_{4}$-supported $\mathrm{Au}-\mathrm{Pd}-x \mathrm{CoO}$ catalysts performed well in $\mathrm{CH}_{4}$ combustion.

The choice of a transition-metal oxide support is important in formulating an effective catalyst because it could provide oxygen vacancies that would be favorable for the adsorption and activation of oxygen and/or VOCs molecules [16,17]. Transition-metal oxides were widely used in catalytic oxidation of VOCs because of their good redox ability [18-21]. Among transition-metal oxides, cobalt oxide was used as support for the removal of VOCs and methane [22-24]. In the previous studies, mesoporous cobalt oxides with high surface areas and ordered pore structures showed better catalytic performance than their nonporous counterparts. For example, Wu et al. [25] reported that 2.94 $\mathrm{Au}_{0.5} \mathrm{Pd} / \mathrm{meso}^{-\mathrm{Co}_{3} \mathrm{O}_{4}}$ performed better than

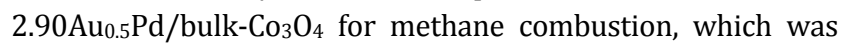
associated with its porous structure, high adsorbed oxygen species concentration, good low-temperature reducibility, and strong interaction between $\mathrm{Au}-\mathrm{Pd}$ alloy NPs and meso- $\mathrm{Co}_{3} \mathrm{O}_{4}$. Liu et al. [26] observed excellent performance for benzene,

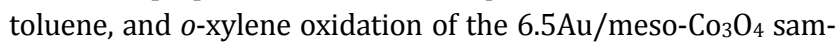
ple with high surface areas.

Previously, our group prepared a series of mesopoorous transition-metal oxides (e.g., meso- $\mathrm{Co}_{3} \mathrm{O}_{4}[25,26]$, meso- $\mathrm{MnO}_{x}$ $[27,28]$, and meso- $\left.\mathrm{CrO}_{x}[29,30]\right)$ via the KIT-6-templating route, and found that most of these porous materials exhibited good performance for VOC combustion. Although a number of bimetal alloy catalysts were reported in the literature, there have been no works on the ternary metal alloy catalysts used for VOC combustion. In the present work, we choose Pd as the major active component, add cheaper noble metals (e.g., Ag and $\mathrm{Au}$ ) to formulate the ternary metal (Ag-Au-Pd) alloy NPs, load them on the surface of meso- $\mathrm{Co}_{3} \mathrm{O}_{4}$, and investigate catalytic properties of the as-obtained materials for the combustion of methanol. It is found that the 0.68 wt $\%$

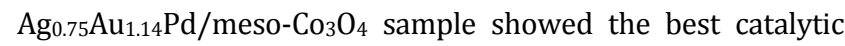
activity for the addressed reaction.

\section{Experimental}

\subsection{Synthesis of meso- $\mathrm{Co}_{3} \mathrm{O}_{4}$}

Three-dimensionally mesoporous silica (KIT-6) was synthesized according to the procedures described by Kleitz et al. [31]. We use KIT- 6 as the hard template and manganese nitrate as the metal source to fabricate the three-dimensionally ordered mesoporous $\mathrm{Co}_{3} \mathrm{O}_{4}$ (meso- $\mathrm{Co}_{3} \mathrm{O}_{4}$ ). In a typical synthesis, $1.0 \mathrm{~g}$ of $\mathrm{Co}\left(\mathrm{NO}_{3}\right)_{2} \cdot 6 \mathrm{H}_{2} \mathrm{O}$ was dissolved in $10 \mathrm{~mL}$ of ethanol, and then $0.5 \mathrm{~g}$ of KIT- 6 was added to the Co-containing ethanol solution. The mixture was stirred at $65^{\circ} \mathrm{C}$ until the solution was dried. The above mixture was placed in a crucible and calcined in a muffle furnace at a ramp of $1{ }^{\circ} \mathrm{C} / \mathrm{min}$ from room temperature (RT) to $600{ }^{\circ} \mathrm{C}$ and kept at this temperature for $6 \mathrm{~h}$. The obtained powders were leached twice with a hot $\mathrm{NaOH}$ aqueous solution $(2.0 \mathrm{~mol} / \mathrm{L})$, followed by washing with deionized water and ethanol two times and drying at $60^{\circ} \mathrm{C}$ for $24 \mathrm{~h}$, thus obtaining the meso- $\mathrm{Co}_{3} \mathrm{O}_{4}$ support.

\subsection{Preparation of meso-Co $\mathrm{Co}_{4}$-supported noble metal catalysts}

The meso- $\mathrm{Co}_{3} \mathrm{O}_{4}$-supported $\mathrm{Ag}_{x} \mathrm{Au}_{y} \mathrm{Pd}(\mathrm{Ag} / \mathrm{Au} / \mathrm{Pd}$ molar ratio $=x: y: 1), \mathrm{Ag}, \mathrm{Au}$, and Pd samples were prepared using the polyvinyl alcohol (PVA)-protected sodium borohydride reduction strategy [28]. The typical preparation procedure is as follows. $2.25 \mathrm{~mL}$ of PVA (MW $=10000 \mathrm{~g} / \mathrm{mol}$ ) was added to (i) a mixture of $0.79,0.34$ or $0.40 \mathrm{~mL}$ of $\mathrm{AgNO}_{3}$ aqueous solution (14.7 mmol/L), $0.56,0.96$ or $0.56 \mathrm{~mL}$ of $\mathrm{HAuCl}_{4}$ aqueous solution $(10.3 \mathrm{mmol} / \mathrm{mL})$, and $0.21,0.18$ or $0.41 \mathrm{~mL}$ of $\mathrm{PdCl}_{2}$ aqueous solution $(28.0 \mathrm{mmol} / \mathrm{mL})$ with the metal $/ \mathrm{PVA}$ mass ratio = $1.0: 1.5$ and the theoretical Ag:Au:Pd molar ratio was 2:1:1, $1: 2: 1$, and $1: 1: 2$, respectively, or (ii) $0.40 \mathrm{~mL}$ of $\mathrm{AgNO}_{3}$ aqueous solution (14.7 mmol/L), or (iii) $0.56 \mathrm{~mL}$ of $\mathrm{HAuCl}_{4}$ aqueous solution $(10.3 \mathrm{mmol} / \mathrm{mL})$, or (iv) $0.41 \mathrm{~mL}$ of $\mathrm{PdCl}_{2}$ aqueous solution $(28.0 \mathrm{mmol} / \mathrm{mL})$ at RT under vigorous stirring for 15 min. After rapidly injecting the $\mathrm{NaBH}_{4}$ aqueous solution $(0.1$ mol/L, and metal $/ \mathrm{NaBH}_{4}$ molar ratio $=1.0: 5.0$ ), a dark-brown sol was generated. $0.3 \mathrm{~g}$ of the meso- $\mathrm{Co}_{3} \mathrm{O}_{4}$ support (the nominal $\mathrm{Ag}_{x} \mathrm{Au}_{y} \mathrm{Pd}$ loading in each of the supported samples was $1.00 \mathrm{wt} \%$; and the nominal $\mathrm{Ag}, \mathrm{Au}$, and Pd loadings in the supported single noble metal samples were $0.42,0.38$, and 0.35 wt\%, respectively) was added to the above dark-brown sol under stirring until complete adsorption (the solution was totally decolorized) was achieved. The obtained mixture was filtered, washed with deionized water, dried at $80{ }^{\circ} \mathrm{C}$ for $12 \mathrm{~h}$, and calcined at a ramp rate of $1^{\circ} \mathrm{C} / \mathrm{min}$ from RT to $500^{\circ} \mathrm{C}$ and maintained this temperature for $2 \mathrm{~h}$. According to the results of the inductively coupled plasma-atomic emission spectroscopic (ICP-AES) characterization, the 0.68 wt $\%$

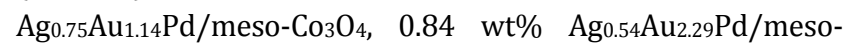
$\mathrm{Co}_{3} \mathrm{O}_{4}, \quad 0.93$ wt $\% \quad \mathrm{Ag}_{0.51} \mathrm{Au} 0.65 \mathrm{Pd} / \mathrm{meso}^{-} \mathrm{Co}_{3} \mathrm{O}_{4}, \quad 0.28$ wt $\%$ 


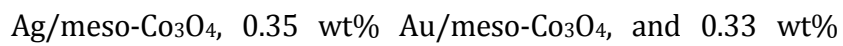
$\mathrm{Pd} / \mathrm{meso}^{-\mathrm{Co}_{3} \mathrm{O}_{4}}$ samples were obtained and denoted as

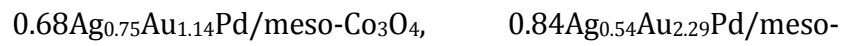
$\mathrm{Co}_{3} \mathrm{O}_{4}, \quad$ 0.93Ag $0.51 \mathrm{Au}_{0.65} \mathrm{Pd} / \mathrm{meso}-\mathrm{Co}_{3} \mathrm{O}_{4}, \quad 0.28 \mathrm{Ag} / \mathrm{meso}-\mathrm{Co}_{3} \mathrm{O}_{4}$, $0.35 \mathrm{Au} / \mathrm{meso}-\mathrm{Co}_{3} \mathrm{O}_{4}$, and $0.33 \mathrm{Pd} / \mathrm{meso}^{-} \mathrm{Co}_{3} \mathrm{O}_{4}$, respectively.

\subsection{Catalyst characterization}

The ICP-AES technique was used to detect the actual metal contents of $\mathrm{Ag}, \mathrm{Au}$, and $\mathrm{Pd}$ in the samples on a Thermo Electron IRIS Intrepid ER/S spectrometer. Before analysis, the sample was dissolved in a mixture of concentrated $\mathrm{HCl}$ and $\mathrm{HNO}_{3}$ with a volumetric ratio of 3:1. X-ray diffraction (XRD) patterns of the samples were recorded on a Bruker D8 Advance diffractometer using the $\mathrm{Cu} K_{\alpha}$ radiation and nickel filter $(\lambda=0.15406 \mathrm{~nm})$. The transmission electron microscopic (TEM) images were obtained on a JEOL JEM-2010 instrument. High angle annular dark field and scanning transmission electron microscopic (HAADF-STEM) techniques were used to record the HAADF-STEM images and EDX element mapping of the typical sample on the equipment FEI G2 80-200/Chemi-STEM Cs-corrected TEM with a probe corrector operated at accelerating voltage $200 \mathrm{kV}$. Before measurements, a small amount of the sample was ultrasonicated in ethanol for $15 \mathrm{~min}$, and the resulting slurry was then deposited on the copper-coated grids. BET (Brunauer-Emmett-Teller) surface areas and pore-size distributions of the samples were measured via $\mathrm{N}_{2}$ adsorption at $-196{ }^{\circ} \mathrm{C}$ on a Micromeritics ASAP 2020 analyzer, with the samples being degassed at $250{ }^{\circ} \mathrm{C}$ for $2.5 \mathrm{~h}$ under vacuum before measurement.

X-ray photoelectron spectroscopy (XPS, Thermo Fisher Scientific ESCALAB $250 \mathrm{Xi}$ ) was used to determine the binding energies (BEs) of Co $2 p, 01 s, \mathrm{Ag} 3 d, \mathrm{Au} 4 f$, Pd $3 d$, and C $1 s$ of surface species using Al $K_{\alpha}(h v=1486.6 \mathrm{eV})$ as excitation source. In order to remove the adsorbed water and carbonate species on the surface, the samples were pretreated in $\mathrm{O}_{2}$ (flow rate $=20 \mathrm{~mL} / \mathrm{min}$ ) at $450{ }^{\circ} \mathrm{C}$ for $1 \mathrm{~h}$ and then cooled to RT, followed by transferring the pretreated samples into the spectrometer in a transparent Glove Bag (Instruments for Research and Industry, USA) filled with helium. The pretreated samples were degassed in the preparation chamber $\left(10^{-5}\right.$ Torr $)$ for $0.5 \mathrm{~h}$ and then introduced into the analysis chamber $\left(3 \times 10^{-9}\right.$ Torr $)$ for XPS spectrum recording. The $\mathrm{C} 1 s$ signal at $\mathrm{BE}=284.6 \mathrm{eV}$ was taken as reference for BE calibration.

Hydrogen temperature-programmed reduction ( $\mathrm{H}_{2}$-TPR) experiments were carried out on a chemical adsorption analyzer (Autochem II 2920, Micromeritics). Before TPR measurement, ca. $0.03 \mathrm{~g}$ of the sample (40-60 mesh) was loaded to a quartz fixed-bed U-shaped microreactor (i.d. $=4 \mathrm{~mm}$ ) and pretreated in an air flow of $30 \mathrm{~mL} / \mathrm{min}$ at $250{ }^{\circ} \mathrm{C}$ for $1 \mathrm{~h}$. After being cooled at the same atmosphere to RT, the pretreated sample was exposed to a flow ( $40 \mathrm{~mL} / \mathrm{min}$ ) of $10 \% \mathrm{H}_{2}-90 \% \mathrm{Ar}$ $(v / v)$ mixture and heated from RT to $450{ }^{\circ} \mathrm{C}$ at a ramp rate of $10{ }^{\circ} \mathrm{C} / \mathrm{min}$. The alteration in $\mathrm{H}_{2}$ concentration of the effluent was monitored online by the chemical adsorption analyzer. The reduction peak was calibrated against that of the complete reduction of a known standard powdered $\mathrm{CuO}$ (Aldrich,
99.995\%).

\subsection{Catalytic activity evaluation}

Catalytic activities of the samples were evaluated in a continuous flow fixed-bed quartz microreactor (i.d. $=4.0 \mathrm{~mm}$ ). 25 $\mathrm{mg}$ of the sample (40-60 mesh) was diluted with $0.15 \mathrm{~g}$ of quartz sands (40-60 mesh) to minimize the effect of hot spots. A thermocouple was placed in the middle of the catalyst bed, and methanol conversion was measured after $1 \mathrm{~h}$ of the reaction that reached a steady state. Before the test, each sample was treated in an oxygen flow of $20 \mathrm{~mL} / \mathrm{min}$ at $250{ }^{\circ} \mathrm{C}$ for $1 \mathrm{~h}$. After being cooled to a given temperature, the reactant gas mixture was passed through the catalyst bed. The total flow rate of reactant gas mixture $\left(0.1\right.$ vol\% methanol $+\mathrm{O}_{2}+\mathrm{N}_{2}$ (balance)) was $33.4 \mathrm{~mL} / \mathrm{min}$, giving a methanol $/ \mathrm{O}_{2}$ molar ratio

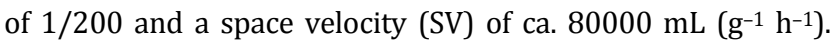
The 0.1 vol\% methanol was generated by passing a $\mathrm{N}_{2}$ flow through a pure methanol-containing bottle that was chilled in an ice-water isothermal bath $\left(0^{\circ} \mathrm{C}\right)$. In the case of water vapor introduction, 3.0 vol $\% \mathrm{H}_{2} \mathrm{O}$ was introduced by passing the feed stream through a water saturator at $33^{\circ} \mathrm{C}$. In the case of $\mathrm{CO}_{2}$ addition, 5.0 vol $\% \mathrm{CO}_{2}$ was introduced from a $\mathrm{CO}_{2}$ cylinder with $\mathrm{N}_{2}$ as the balanced gas. Reactants and products were analyzed online on a gas chromatograph (GC-2010, Shimadzu) equipped with a flame ionization detector (FID), using a stabilwax@-DA column (30 m in length) for methanol separation. Catalytic activities of the samples were evaluated using the temperatures $\left(T_{50 \%}\right.$ and $\left.T_{90 \%}\right)$ required for achieving methanol conversions of $50 \%$ and $90 \%$, respectively. Methanol conversion was defined as $\left(c_{\text {inlet }}-c_{\text {outlet }}\right) / c_{\text {inlet }} \times 100 \%$, where $c_{\text {inlet }}$ and $c_{\text {outlet }}$ are toluene concentrations of the inlet and outlet feed stream, respectively. Only $\mathrm{CO}_{2}$ was detected in the outlet. The balance of carbon throughout the investigation was estimated to be $98.5 \%$ $\pm 1.5 \%$. Reaction rate per gram of noble metal was calculated according to the following formula: $r=c_{\mathrm{R}, \text { in }} \times X / m_{\text {noble metal, }}$ where $c_{\mathrm{R}, \mathrm{in}}(\mathrm{mol} / \mathrm{s})$ is the initial reactant concentration, $X$ is the methanol conversion rate, and $m_{\text {noble metal }}(\mathrm{g})$ is the mass of the catalyst.

\section{Results and discussion}

\subsection{Crystal phase composition, surface morphology, pore structure, and surface area}

Fig. 1 shows the wide-angle XRD patterns of the as-prepared samples. All of the diffraction peaks can be well indexed, as indicated in Fig. 1g. By referring to the XRD pattern (JCPDS PDF\# 42-1467) of the standard $\mathrm{Co}_{3} \mathrm{O}_{4}$ sample, one can realize that the $\mathrm{Co}_{3} \mathrm{O}_{4}$ support was cubic in crystal structure [32,33], and the appearance of a signal at $2 \theta \approx 1^{\circ}$ in the small-angle XRD pattern (not shown here) suggests generation of an ordered mesoporous structure in the $\mathrm{Co}_{3} \mathrm{O}_{4}$ support, which was synthesized using the same procedures described in our previous works $[15,26]$. There were no apparent differences in XRD patterns of the supported noble metal samples, indicating that the loading of noble metal NPs did not change the structure of the 


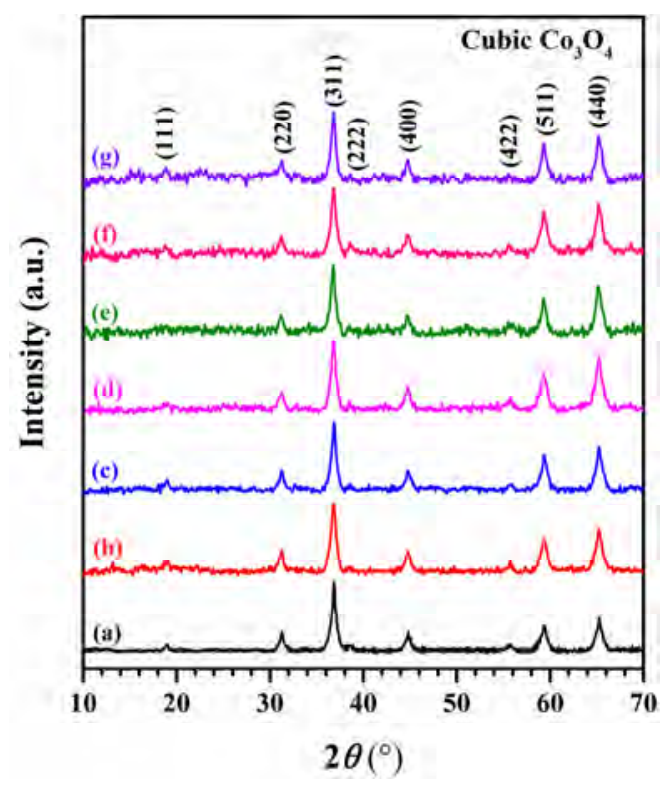

Fig. 1. Wide-angle XRD patterns of (a) meso- $\mathrm{Co}_{3} \mathrm{O}_{4}$, (b) $0.28 \mathrm{Ag} / \mathrm{meso}-\mathrm{Co}_{3} \mathrm{O}_{4}$, (c) $0.35 \mathrm{Au} / \mathrm{meso}-\mathrm{Co}_{3} \mathrm{O}_{4}$, (d) $0.33 \mathrm{Pd} / \mathrm{meso}-\mathrm{Co}_{3} \mathrm{O}_{4}$, (e) $0.68 \mathrm{Ag}_{0.75} \mathrm{Au}_{1.14} \mathrm{Pd} / \mathrm{meso}-\mathrm{Co}_{3} \mathrm{O}_{4}$, (f) $0.84 \mathrm{Ag}_{0.54} \mathrm{Au}_{2.22} \mathrm{Pd} / \mathrm{meso}-\mathrm{Co}_{3} \mathrm{O}_{4}$, and $(\mathrm{g}) 0.93 \mathrm{Ag}_{0.51} \mathrm{Au}_{0.65} \mathrm{Pd} / \mathrm{meso}^{-} \mathrm{Co}_{3} \mathrm{O}_{4}$.

support and the noble metal NPs were highly dispersed on the surface of meso- $\mathrm{Co}_{3} \mathrm{O}_{4}$.

TEM images shown in Fig. 2 demonstrate that a 3D ordered mesoporous structure was formed in the samples, and the mesopore diameter of meso- $\mathrm{Co}_{3} \mathrm{O}_{4}$ was ca. $6 \mathrm{~nm}$. Ag, Au, Pd, and $\mathrm{Ag}_{x} \mathrm{Au}_{y} \mathrm{Pd}$ NPs were uniformly dispersed on the surface of meso- $\mathrm{Co}_{3} \mathrm{O}_{4}$. The HAADF-STEM images of the $0.68 \mathrm{Ag}_{0.75} \mathrm{Au}_{1.14} \mathrm{Pd} /$
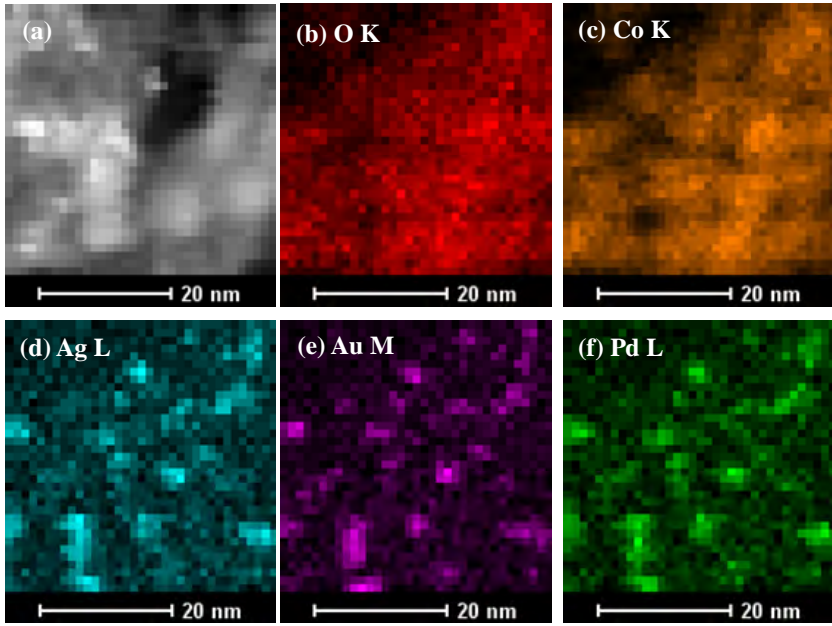

Fig. 3. HAADF-STEM and elemental scanning images of the $0.68 \mathrm{Ag}_{0.75} \mathrm{Au}_{1.14} \mathrm{Pd} / \mathrm{meso}^{-\mathrm{Co}_{3} \mathrm{O}_{4} \text { sample. }}$

meso- $\mathrm{Co}_{3} \mathrm{O}_{4}$ sample is shown in Fig. 3. It can be obviously seen that the NPs in the selected region were composed of $\mathrm{Ag}, \mathrm{Au}$, and $\mathrm{Pd}$, indicating formation of the Ag-Au-Pd alloy in $\mathrm{Ag}_{0.75} \mathrm{Au}_{1.14} \mathrm{Pd}$ NPs. After statistically analyzing 100 noble metal NPs in the TEM images, we measured their average sizes and the results are shown in Fig. 4. As summarized in Table 1, the average sizes of $\mathrm{Ag}, \mathrm{Au}$, and Pd NPs were 4.1, 4.5, and $2.8 \mathrm{~nm}$, respectively, while those of $\mathrm{Ag}_{x} \mathrm{Au}_{y} \mathrm{Pd}$ NPs were $2.9-3.0 \mathrm{~nm}$ (Fig. 4).

$\mathrm{N}_{2}$ adsorption-desorption isotherms and pore-size distributions of the samples are shown in Fig. $5 \mathrm{~A}$ and B, respectively. All of the samples exhibited a type IV isotherm with a H1 hys-

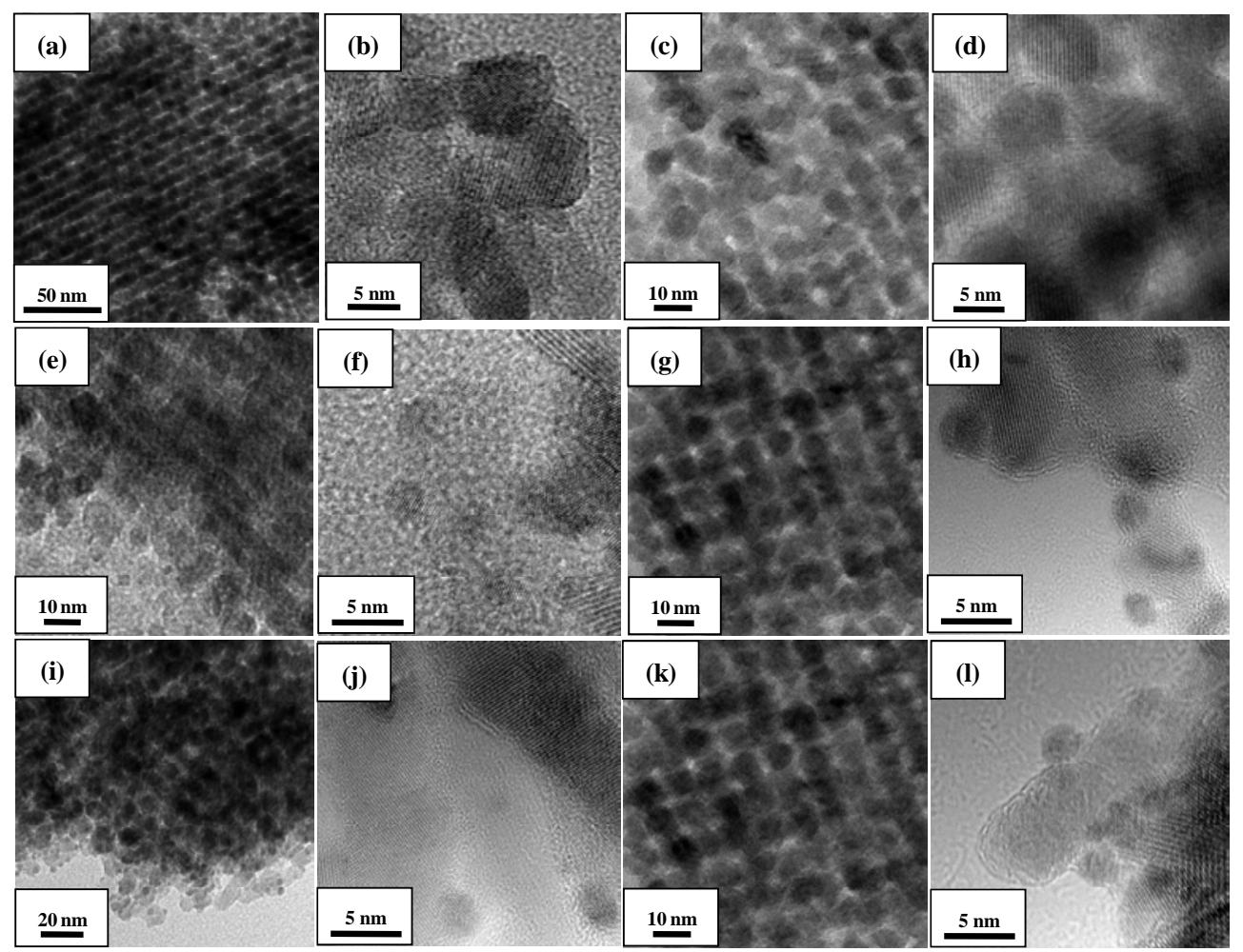

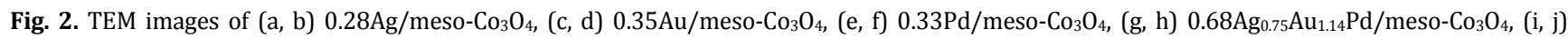

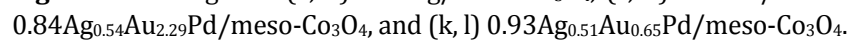



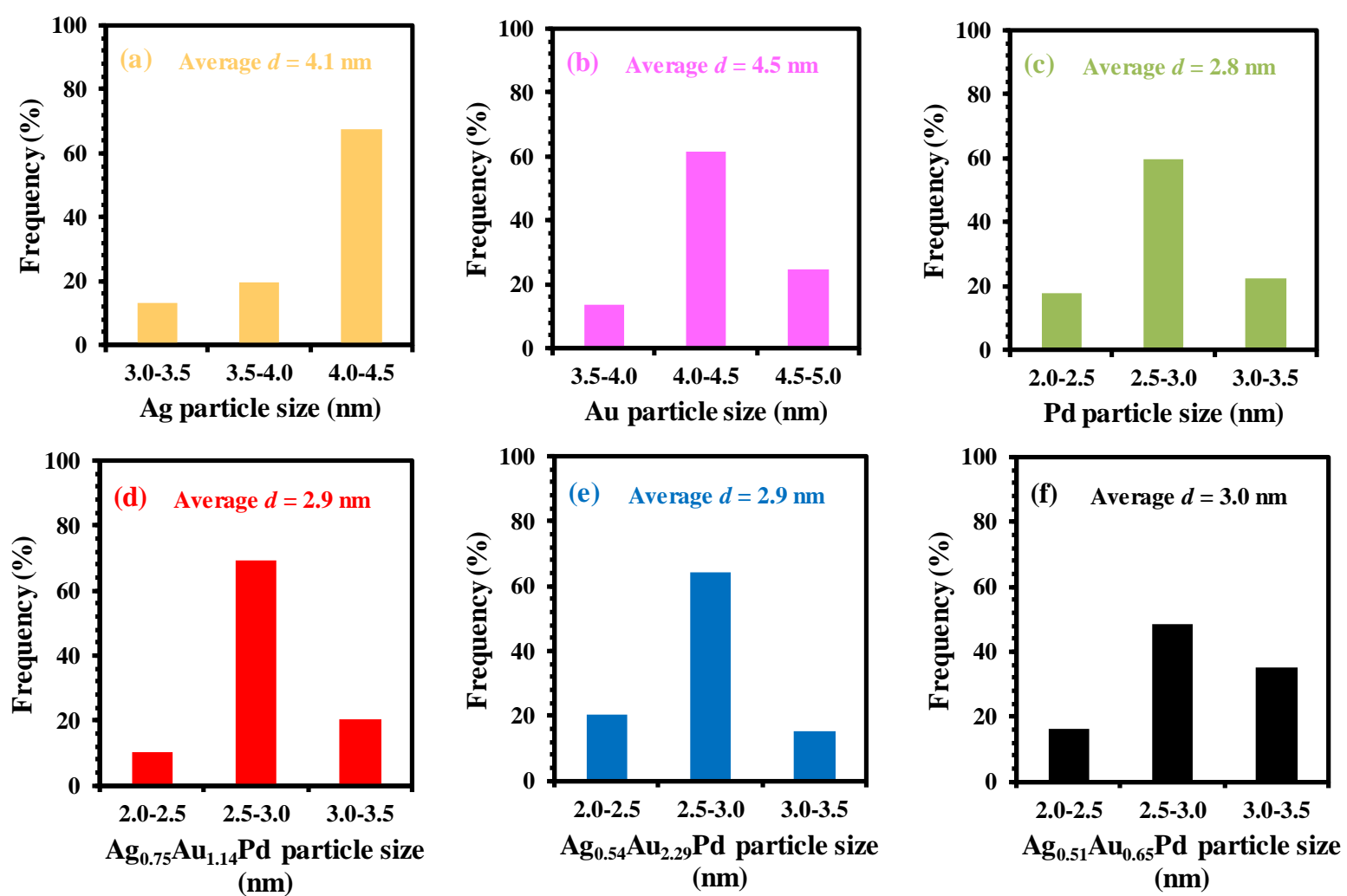

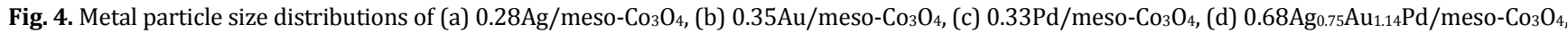
(e) $0.84 \mathrm{Ag}_{0.54} \mathrm{Au}_{2.29} \mathrm{Pd} / \mathrm{meso}-\mathrm{Co}_{3} \mathrm{O}_{4}$, and (f) $0.93 \mathrm{Ag}_{0.51} \mathrm{Au}_{0.65} \mathrm{Pd} / \mathrm{meso}-\mathrm{Co}_{3} \mathrm{O}_{4}$.

Table 1

BET surface areas, average pore diameters, pore volumes, average noble metal particle sizes, actual noble metal molar ratios, and actual noble metal loadings of the as-obtained samples.

\begin{tabular}{|c|c|c|c|c|c|c|c|c|c|}
\hline \multirow{2}{*}{ Sample } & \multirow{2}{*}{$\begin{array}{c}\text { Surface } \\
\text { area }\left(\mathrm{m}^{2} / \mathrm{g}\right)\end{array}$} & \multirow{2}{*}{$\begin{array}{c}\text { Average pore } \\
\text { diameter (nm) }\end{array}$} & \multirow{2}{*}{$\begin{array}{l}\text { Pore volume } \\
\left(\mathrm{cm}^{3} / \mathrm{g}\right)\end{array}$} & \multicolumn{6}{|c|}{ Average noble metal Actual Ag:Au:Pd Actual noble metal loading b $(\mathrm{wt} \%)$} \\
\hline & & & & particle size ${ }^{a}(\mathrm{~nm})$ & molar ratio ${ }^{\mathrm{b}}$ & $\mathrm{Ag}$ & $\mathrm{Au}$ & $\mathrm{Pd}$ & Total \\
\hline meso- $\mathrm{Co}_{3} \mathrm{O}_{4}$ & 125 & 6.1 & 0.14 & - & - & - & - & - & - \\
\hline $0.28 \mathrm{Ag} / \mathrm{meso}^{-\mathrm{Co}_{3} \mathrm{O}_{4}}$ & 119 & 6.0 & 0.15 & 4.1 & - & 0.28 & - & - & 0.28 \\
\hline $0.35 \mathrm{Au} / \mathrm{meso}-\mathrm{Co}_{3} \mathrm{O}_{4}$ & 120 & 5.8 & 0.16 & 4.5 & - & - & 0.35 & - & 0.35 \\
\hline $0.33 \mathrm{Pd} / \mathrm{meso}-\mathrm{Co}_{3} \mathrm{O}_{4}$ & 115 & 5.8 & 0.16 & 2.8 & - & - & - & 0.33 & 0.33 \\
\hline $0.68 \mathrm{Ag}_{0.75} \mathrm{Au}_{1.14} \mathrm{Pd} / \mathrm{meso}-\mathrm{Co}_{3} \mathrm{O}_{4}$ & 120 & 5.9 & 0.16 & 2.9 & 0.75:1.14:1.00 & 0.13 & 0.37 & 0.18 & 0.68 \\
\hline $0.84 \mathrm{Ag}_{0.54} \mathrm{Au}_{2.29} \mathrm{Pd} / \mathrm{meso}^{-\mathrm{Co}_{3} \mathrm{O}_{4}}$ & 119 & 5.8 & 0.16 & 2.9 & $0.54: 2.29: 1.00$ & 0.08 & 0.62 & 0.14 & 0.84 \\
\hline $0.93 \mathrm{Ag}_{0.51} \mathrm{Au}_{0.65} \mathrm{Pd} / \mathrm{meso}-\mathrm{Co}_{3} \mathrm{O}_{4}$ & 120 & 5.7 & 0.16 & 3.0 & 0.51:0.65:1.00 & 0.18 & 0.41 & 0.34 & 0.93 \\
\hline
\end{tabular}

a Determined according to the TEM images of the samples.

b Determined by the ICP-AES technique.

teresis loop in the relative pressure $\left(p / p_{0}\right)$ range of $0.4-1.0$, demonstrating the generation of ordered mesopores. There was a peak in the pore-size range of 5.7-6.0 nm of each sample (Fig. 5B), further confirming the presence of mesopores in these samples. The above results were in good accordance with those of the small-angle XRD and TEM investigations. Surface areas and pore volumes of the samples are summarized in Table 1 . The surface area, average pore size, and pore volume of meso- $\mathrm{Co}_{3} \mathrm{O}_{4}$ were $125 \mathrm{~m}^{2} / \mathrm{g}, 6.1 \mathrm{~nm}$, and $0.14 \mathrm{~cm}^{3} / \mathrm{g}$, respectively. After loading noble metal NPs on the support, however, there were no significant decreases in surface area of the supported noble metal samples. The supported noble metal samples possessed a surface area of $115-120 \mathrm{~m}^{2} / \mathrm{g}$, an average pore size of $5.7-6.0 \mathrm{~nm}$, and a pore volume of $0.15-0.16 \mathrm{~cm}^{3} / \mathrm{g}$ (Table 1).

\subsection{Surface element composition, metal oxidation state, and adsorbed oxygen species}

XPS technique was applied to investigate the surface element compositions, metal oxidation states, and adsorbed oxygen species of the samples. Fig. 6 shows the Co $2 p_{3 / 2}, \mathrm{O} 1 \mathrm{~s}, \mathrm{Ag}$ $3 d_{5 / 2}$, Au $4 f$, and Pd $3 d$ XPS spectra of the samples. By using the curve-fitting method, we can decompose the Co $2 p_{3 / 2}$ into three components (Fig. 6A): the ones at binding energy (BE) $=779.8$ and $781.5 \mathrm{eV}$ were assigned to the surface $\mathrm{Co}^{3+}$ and $\mathrm{Co}^{2+}$ species, respectively, whereas the one at $\mathrm{BE}=788.9 \mathrm{eV}$ was attributed to the satellite signal of the surface $\mathrm{Co}^{2+}$ species $[34,35]$. The asymmetrical $01 s$ XPS signals could be decomposed into three components at $\mathrm{BE}=529.9,531.3$, and 532.7 

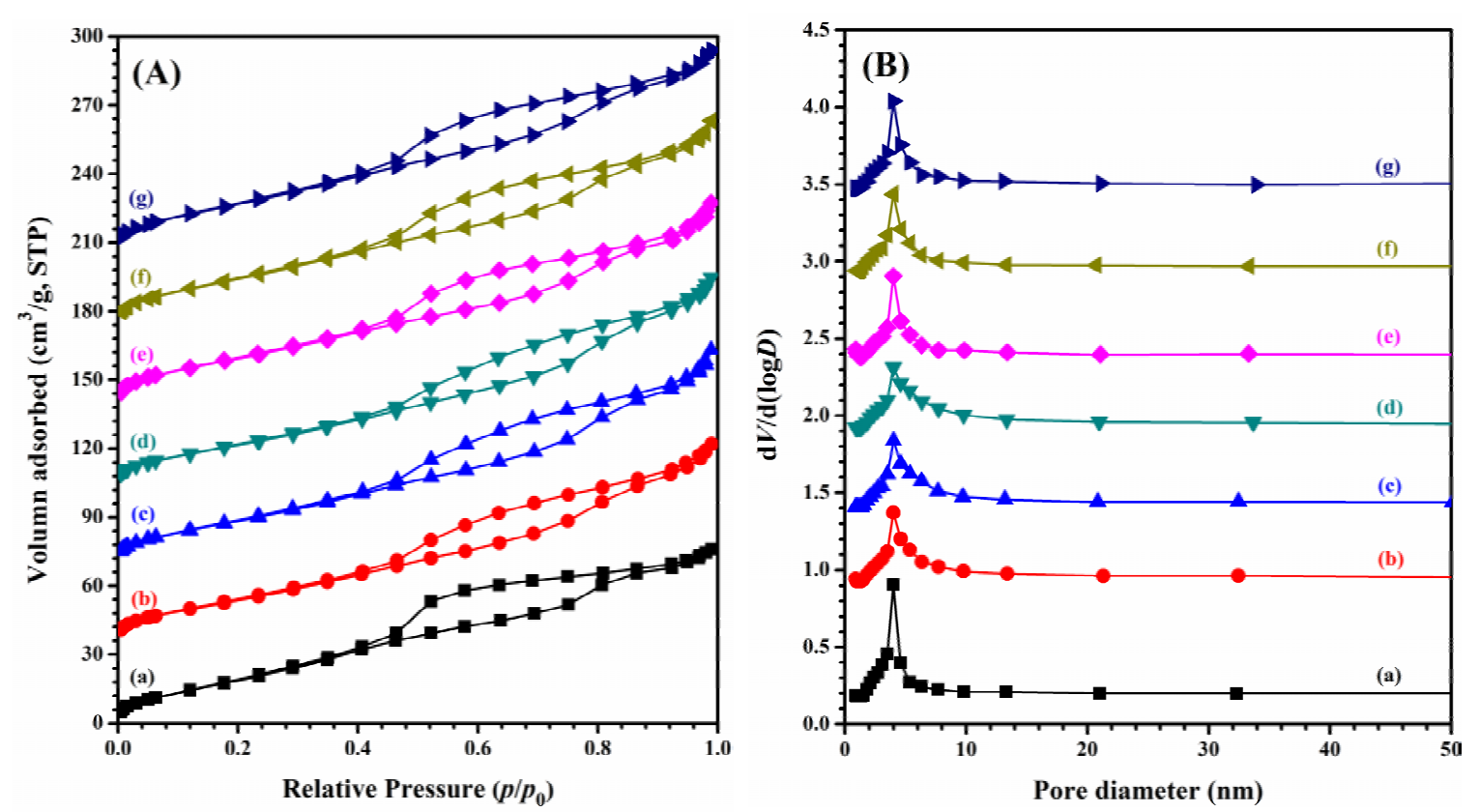

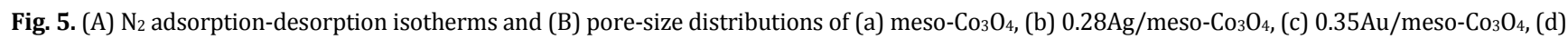

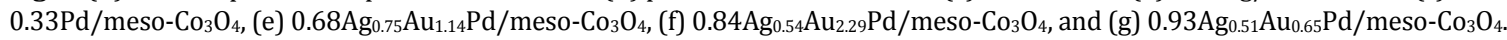

$\mathrm{eV}$ (Fig. 6B), ascribable to the surface lattice oxygen ( $\left.\mathrm{O}_{\text {latt }}\right)$, adsorbed oxygen $\left(\mathrm{O}_{\text {ads, }}\right.$ e.g., $\mathrm{O}_{2}{ }^{-}, \mathrm{O}_{2} 2^{-}$or $\left.\mathrm{O}^{-}\right)$, and adsorbed molecular water or carbonate species [36], respectively. It is well known that there is a close link between the ability to activate oxygen and the activity of a catalyst. The electrophilic $\mathrm{O}_{2}{ }^{-}, \mathrm{O}_{2}{ }^{2-}$ or $\mathrm{O}^{-}$species can play an important role in the oxidation of organics. The supported $\mathrm{Ag}_{x} \mathrm{Au}_{y} \mathrm{Pd}$ NPs possessed much higher amounts of the $\mathrm{O}_{\text {ads }}$ species than the supported $\mathrm{Ag}, \mathrm{Au}$ or $\mathrm{Pd}$ NPs, making the former outperform the latter for methanol combustion, as confirmed by their activity data. The broad and asymmetrical Ag $3 d_{5 / 2}$ XPS signal of each sample could be deconvoluted into two components at $\mathrm{BE}=367.5$ and $368.0 \mathrm{eV}$, which was ascribed to the surface $\mathrm{Ag}^{+}$and $\mathrm{Ag}^{0}$ species $[37,38]$, respectively. The Au XPS signal of each sample could be decomposed into four components (Fig. 6D): the ones at $\mathrm{BE}=84.0$ and $87.7 \mathrm{eV}$ were attributed to the surface $\mathrm{Au}^{0}$ species, whereas the ones at $\mathrm{BE}=85.1$ and $88.7 \mathrm{eV}$ were assigned to the surface $\mathrm{Au}^{\delta+}$ species [39]. As shown in Fig. 6E, the Pd $3 d$ XPS signal was decomposed into two sets of components: the ones at $\mathrm{BE}=$ 335.5 and $340.7 \mathrm{eV}$ were assignable to the surface $\mathrm{Pd}^{0}$ species, while the ones at $\mathrm{BE}=337.2$ and $342.4 \mathrm{eV}$ were attributable to the surface $\mathrm{Pd}^{2+}$ species $[40,41]$. A higher $\mathrm{Pd}^{2+} / \mathrm{Pd}^{0}$ molar ratio could also favor the improvement in catalytic activity because $\mathrm{Pd}^{2+}$ was the active site for activation of VOCs. The surface element compositions of the samples are summarized in Table 2. After loading $\mathrm{Ag}_{x} \mathrm{Au}_{y} \mathrm{Pd} \mathrm{NPs}$ on meso- $\mathrm{Co}_{3} \mathrm{O}_{4}$, the surface $\mathrm{Co}^{3+} / \mathrm{Co}^{2+}$ molar ratio decreased from $0.80-0.90$ to $0.60-0.69$ (Table 2), indicating that the surface $\mathrm{Co}^{2+}$ concentration increased. Such a decrease in $\mathrm{Co}^{3+} / \mathrm{Co}^{2+}$ molar ratio as well as formation of the $\mathrm{Au}^{\delta+}, \mathrm{Ag}^{+}$, and $\mathrm{Pd}^{2+}$ species was due to the enhanced strong interaction between noble metal NPs and support. Obviously, the $0.68 \mathrm{Ag}_{0.75} \mathrm{Au}_{1.14} \mathrm{Pd} / \mathrm{meso}^{-\mathrm{Co}_{3} \mathrm{O}_{4}}$ sample possessed the lowest surface $\mathrm{Co}^{3+} / \mathrm{Co}^{2+}$ molar ratio. In other words, there was the highest oxygen vacancy concentration on the surface of $0.68 \mathrm{Ag}_{0.75} \mathrm{Au}_{1.14} \mathrm{Pd} /$ meso- $\mathrm{Co}_{3} \mathrm{O}_{4}$. A more amount of oxygen vacancies can give rise to a more amount of the $\mathrm{O}_{\text {ads }}$ species, consequently resulting in a better performance of a catalyst. Therefore, it is understandable that the $0.68 \mathrm{Ag}_{0.75} \mathrm{Au}_{1.14} \mathrm{Pd} / \mathrm{meso}-\mathrm{Co}_{3} \mathrm{O}_{4}$ sample showed the best activity for the oxidation of methanol.

\subsection{Reducibility}

$\mathrm{H}_{2}$-TPR profiles of the samples are shown in Fig. 7A. According to the literature, the two reduction peaks at 300 and $320-410{ }^{\circ} \mathrm{C}$ of the $\mathrm{Co}_{3} \mathrm{O}_{4}$ sample were ascribable to reduction of $\mathrm{Co}^{3+}$ to $\mathrm{Co}^{2+}$ and of $\mathrm{Co}^{2+}$ to $\mathrm{Co}^{0}[42,43]$, respectively. After loading $\mathrm{Ag}$ and $\mathrm{Au}$, the newly appeared peaks at 200 and $265^{\circ} \mathrm{C}$ were attributable to the reduction of these noble metal oxides. When Pd or $\mathrm{Ag}_{x} \mathrm{Au}_{y} \mathrm{Pd}$ was loaded on the surface of meso- $\mathrm{Co}_{3} \mathrm{O}_{4}$, the reduction peaks were significantly shifted to low temperatures (the first peak at $115{ }^{\circ} \mathrm{C}$ was mainly due to reduction of $\mathrm{PdO}_{x}$, and the reduction of $\mathrm{Co}^{3+}$ and $\mathrm{Co}^{2+}$ was shifted to a lower temperature, which indicates the presence of a strong interaction between noble metal alloy NPs and support). Such a phenomenon was a result due to reduction of meso- $\mathrm{Co}_{3} \mathrm{O}_{4}$ promoted by the hydrogen chemically adsorbed on $\mathrm{Pd}$ or $\mathrm{Ag}_{x} \mathrm{Au} y \mathrm{Pd}$ NPs. The results demonstrate that loading of $\mathrm{Pd}$ or $\mathrm{Ag}_{x} \mathrm{Au}_{y} \mathrm{Pd}$ NPs considerably improved the low-temperature reducibility of the sample. By quantitatively analyzing the reduction peaks in the $\mathrm{H}_{2}$-TPR profiles, one can obtain the $\mathrm{H}_{2}$ consumption of the samples, as summarized in Table 2. The $\mathrm{H}_{2}$ consumptions of the samples were in the range of $19.6-21.0 \mathrm{mmol} / \mathrm{g}_{\text {cat }}$ (slightly higher than the theoretical $\mathrm{H}_{2}$ consumption of $\mathrm{Co}_{3} \mathrm{O}_{4}$ ), which was due to the reduction of the oxidized noble metal NPs and the removal of the adsorbed oxygen species.

The initial $\mathrm{H}_{2}$ consumption rate was calculated according to the $\mathrm{H}_{2}$ consumption per gram of catalyst per second, which 

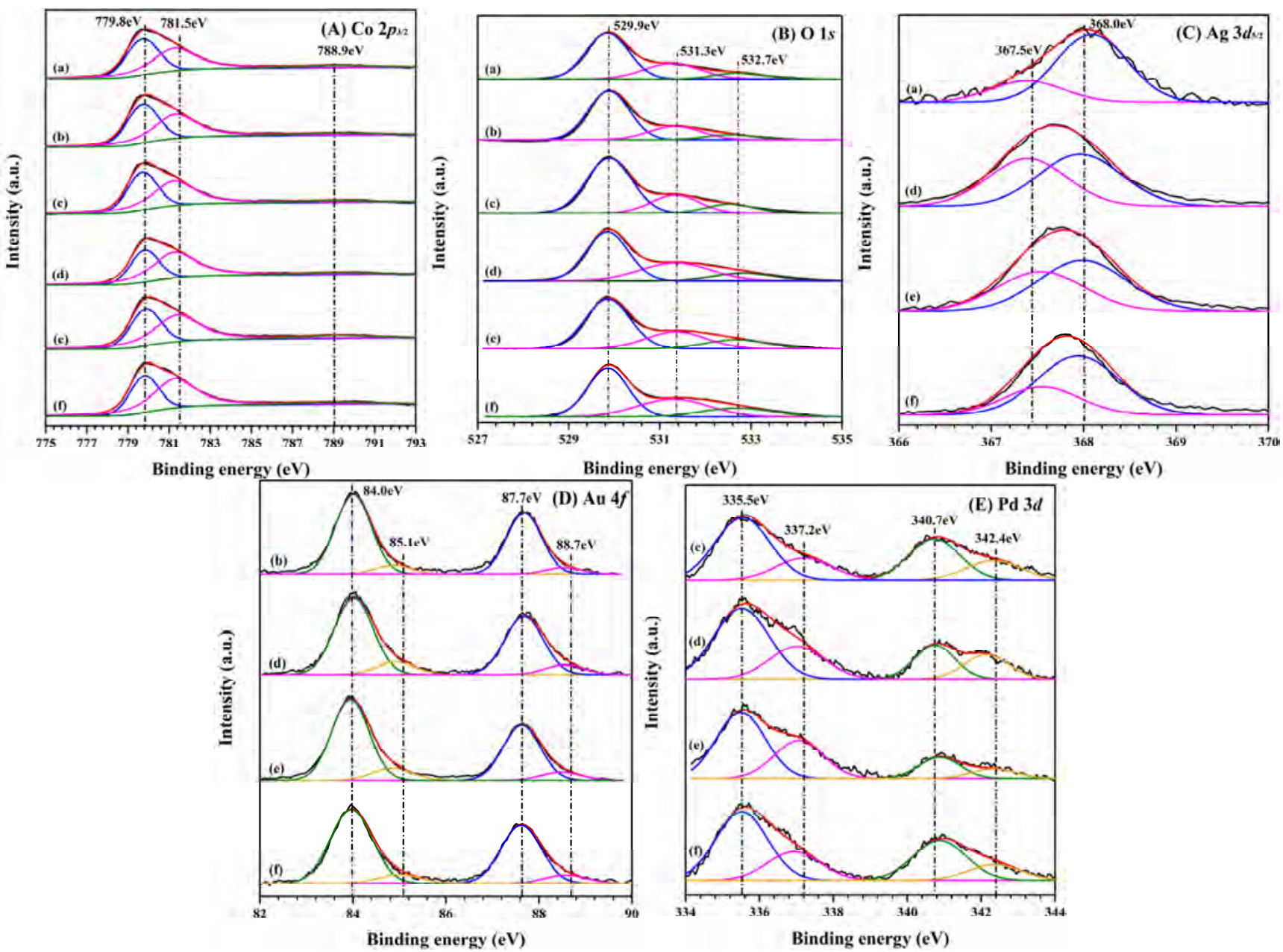

Fig. 6. (A) Co $2 p_{3 / 2}$, (B) $\mathrm{O} 1 \mathrm{~s}$, (C) $\mathrm{Ag} 3 d_{5 / 2}$, (D) Au 4f, and (E) Pd $3 d$ XPS spectra of (a) $0.28 \mathrm{Ag} / \mathrm{meso}-\mathrm{Co}_{3} \mathrm{O}_{4}$, (b) $0.35 \mathrm{Au} / \mathrm{meso}^{-\mathrm{Co}} \mathrm{O}_{4}$, (c)

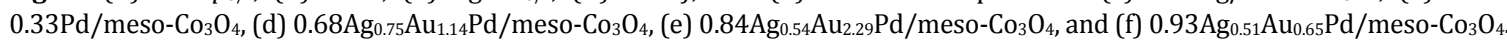

Table 2

Surface element compositions, $\mathrm{H}_{2}$ consumption, catalytic activities, and $\mathrm{TOF}_{\text {noble metal }}$ at $\mathrm{SV}=80000 \mathrm{~mL} \mathrm{~g}^{-1} \mathrm{~h}^{-1}$ of the samples.

\begin{tabular}{|c|c|c|c|c|c|c|c|c|c|}
\hline \multirow{2}{*}{ Sample } & \multicolumn{5}{|c|}{ Surface element composition a $(\mathrm{mol} / \mathrm{mol})$} & \multirow{2}{*}{$\begin{array}{c}\mathrm{H}_{2} \text { consumption } \mathrm{b} \\
\left(\mathrm{mmol} / \mathrm{g}_{\mathrm{cat}}\right)\end{array}$} & \multicolumn{2}{|c|}{ Catalytic activity } & \multirow{2}{*}{$\begin{array}{c}\text { TOF } \\
100^{\circ} \mathrm{C}\left(10^{-3} \mathrm{~s}^{-1}\right)\end{array}$} \\
\hline & $\mathrm{Co}^{3+} / \mathrm{Co}^{2+}$ & $\mathrm{Ag}^{+} / \mathrm{Ag}^{0}$ & $\mathrm{Au}^{\delta+} / \mathrm{Au}^{0}$ & $\mathrm{Pd}^{2+} / \mathrm{Pd}^{0}$ & $\mathrm{O}_{\text {ads }} / \mathrm{O}_{\text {latt }}$ & & $T_{50 \%}\left({ }^{\circ} \mathrm{C}\right)$ & $T_{90 \%}\left({ }^{\circ} \mathrm{C}\right)$ & \\
\hline $0.28 \mathrm{Ag} / \mathrm{meso}-\mathrm{Co}_{3} \mathrm{O}_{4}$ & 0.90 & 0.32 & - & - & 0.33 & 19.9 & 148 & 176 & 2.8 \\
\hline $0.35 \mathrm{Au} / \mathrm{meso}^{-} \mathrm{Co}_{3} \mathrm{O}_{4}$ & 0.88 & - & 0.11 & - & 0.34 & 21.0 & 144 & 174 & 4.3 \\
\hline $0.33 \mathrm{Pd} / \mathrm{meso}^{-\mathrm{Co}_{3} \mathrm{O}_{4}}$ & 0.80 & - & - & 0.42 & 0.36 & 19.6 & 124 & 162 & 5.1 \\
\hline $0.68 \mathrm{Ag}_{0.75} \mathrm{Au}_{1.14} \mathrm{Pd} / \mathrm{meso}^{-\mathrm{Co}_{3} \mathrm{O}_{4}}$ & 0.60 & 0.87 & 0.17 & 0.55 & 0.63 & 20.9 & 100 & 112 & 13.0 \\
\hline $0.84 \mathrm{Ag}_{0.54} \mathrm{Au}_{2.29} \mathrm{Pd} / \mathrm{meso}^{-\mathrm{Co}_{3} \mathrm{O}_{4}}$ & 0.69 & 0.77 & 0.17 & 0.56 & 0.44 & 19.8 & 109 & 140 & 6.8 \\
\hline $0.93 \mathrm{Ag}_{0.51} \mathrm{Au}_{0.65} \mathrm{Pd} /$ meso- $\mathrm{Co}_{3} \mathrm{O}_{4}$ & 0.63 & 0.44 & 0.13 & 0.42 & 0.60 & 20.1 & 105 & 126 & 5.5 \\
\hline
\end{tabular}

a Calculated by quantitatively analyzing the peaks in XPS spectra of the samples.

${ }^{\mathrm{b}}$ Calculated by quantitatively analyzing the peaks in $\mathrm{H}_{2}$-TPR profiles of the samples.

corresponded to the initial $25 \%$ of the first reduction peak where no phase transformation of the sample occurred [44,45]. The results are shown in Fig. 7B. The initial $\mathrm{H}_{2}$ consumption rate increased in the sequence of $0.28 \mathrm{Ag} / \mathrm{meso}-\mathrm{Co}_{3} \mathrm{O}_{4}<$ $0.35 \mathrm{Au} / \mathrm{meso}^{-\mathrm{Co}_{3} \mathrm{O}_{4}<0.33 \mathrm{Pd} / \text { meso- }^{-} \mathrm{Co}_{3} \mathrm{O}_{4}<}$ $0.84 \mathrm{Ag}_{0.54} \mathrm{Au}_{2.29} \mathrm{Pd} / \mathrm{meso}-\mathrm{Co}_{3} \mathrm{O}_{4}<0.93 \mathrm{Ag}_{0.51} \mathrm{Au}_{0.65} \mathrm{Pd} / \mathrm{meso}-$

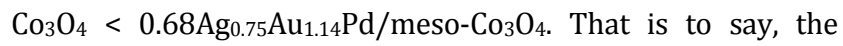
$0.68 \mathrm{Ag}_{0.75} \mathrm{Au}_{1.14} \mathrm{Pd} / \mathrm{meso}^{-\mathrm{Co}_{3} \mathrm{O}_{4}}$ sample exhibited the best low-temperature reducibility. The trend in low-temperature reducibility was in agreement with the order in catalytic activi- ty of the samples (shown below).

\subsection{Catalytic performance}

No significant methanol conversions $(<2 \%)$ at temperature $<220{ }^{\circ} \mathrm{C}$ and SV $=80000 \mathrm{~mL} \mathrm{~g}^{-1} \mathrm{~h}^{-1}$ were detected in the blank experiment (only quartz sands were loaded in the microreactor), indicating that no considerable gas-phase reaction existed in the catalytic system. Fig. 8A shows the catalytic activities of the as-prepared samples at SV $=80000 \mathrm{~mL} \mathrm{~g}^{-1} \mathrm{~h}^{-1}$. Obviously, 

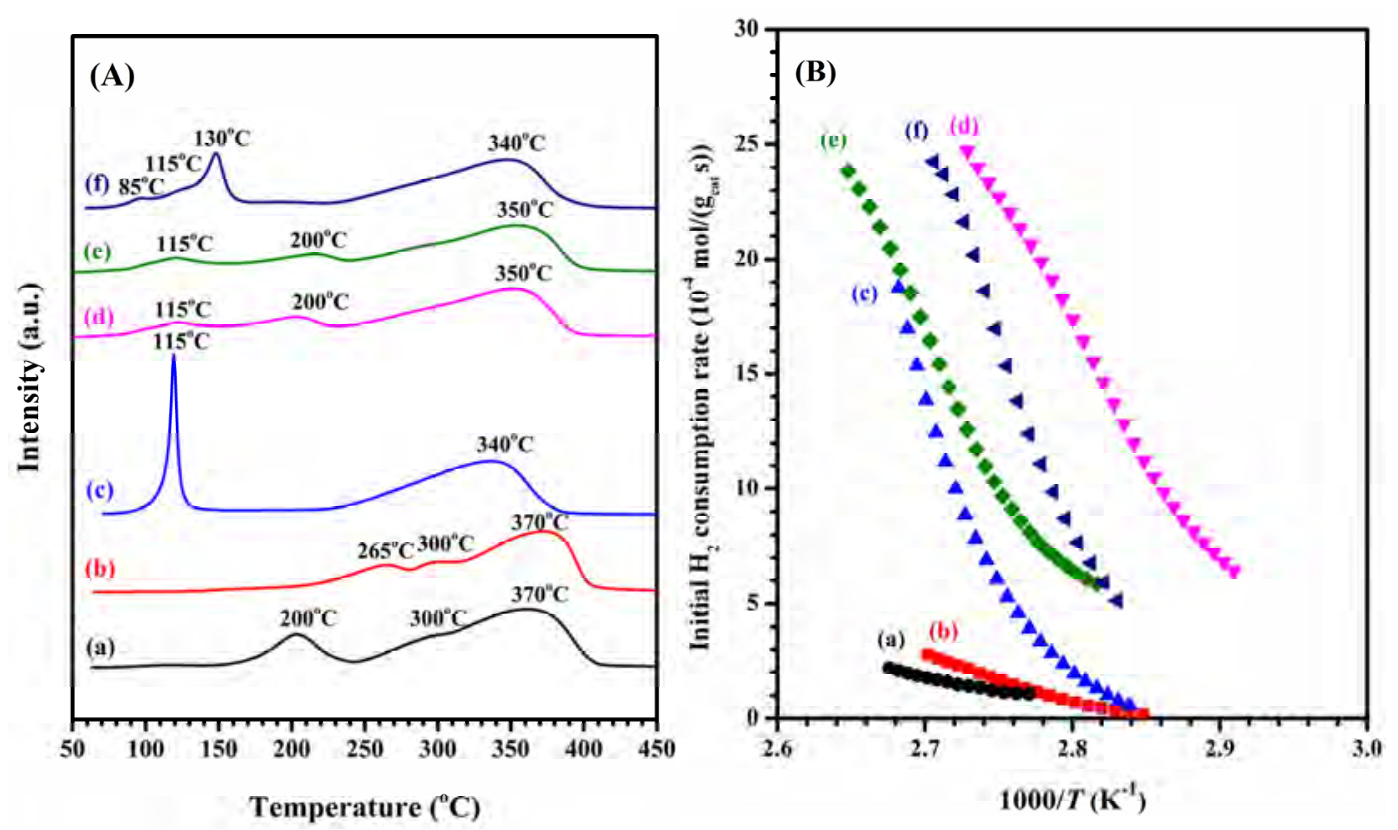

Fig. 7. (A) $\mathrm{H}_{2}$-TPR profiles and (B) initial $\mathrm{H}_{2}$ consumption rate of (a) $0.28 \mathrm{Ag} / \mathrm{meso}-\mathrm{Co}_{3} \mathrm{O}_{4}$, (b) $0.35 \mathrm{Au} / \mathrm{meso}^{-\mathrm{Co}} \mathrm{O}_{4},(\mathrm{c})$ 0.33Pd/meso-Co $\mathrm{O}_{4}$, (d)

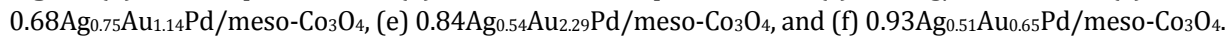

the supported $\mathrm{Ag}_{x} \mathrm{Au}_{y} \mathrm{Pd}$ samples outperformed the supported $\mathrm{Ag}, \mathrm{Au}$ or Pd sample. Among the supported $\mathrm{Ag}_{x} \mathrm{Au}_{y} \mathrm{Pd}$ samples, catalytic activity decreased in the order of 0.68 $\mathrm{Ag}_{0.75} \mathrm{Au}_{1.14} \mathrm{Pd} / \mathrm{meso}-\mathrm{Co}_{3} \mathrm{O}_{4}>0.93 \mathrm{Ag}_{0.51} \mathrm{Au}_{0.65} \mathrm{Pd} / \mathrm{meso}-$

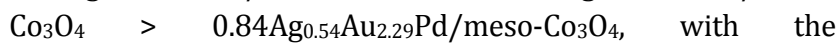

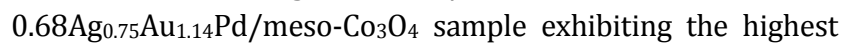
activity $\left(T_{50 \%}=100{ }^{\circ} \mathrm{C}\right.$ and $T_{90 \%}=112{ }^{\circ} \mathrm{C}$ at SV $=80000 \mathrm{~mL} \mathrm{~g}^{-1}$ $\mathrm{h}^{-1}$. Fig. 8B shows the methanol reaction rate normalized per gram of noble metal versus temperature of the samples. It can be seen that the $0.28 \mathrm{Ag} /$ meso- $\mathrm{Co}_{3} \mathrm{O}_{4}$ sample almost showed the

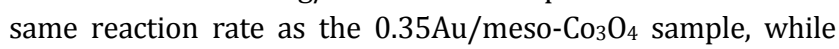
the supported Pd sample performed better than the supported $\mathrm{Ag}$ or Au sample. The reaction rate decreased in the order of

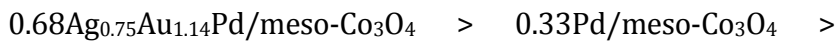
$0.93 \mathrm{Ag}_{0.51} \mathrm{Au}_{0.65} \mathrm{Pd} / \mathrm{meso}-\mathrm{Co}_{3} \mathrm{O}_{4} \approx 0.84 \mathrm{Ag}_{0.54} \mathrm{Au}_{2.29} \mathrm{Pd} / \mathrm{meso}-$

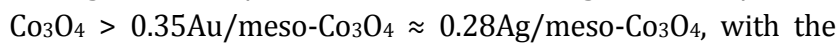

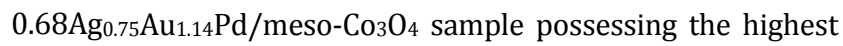
catalytic efficiency. The turnover frequencies (TOF ${ }_{\text {noble metal }}$ normalized per gram of noble metal at $100{ }^{\circ} \mathrm{C}\left(\times 10^{-3} \mathrm{~s}^{-1}\right)$ were calculated and summarized in Table 2. The

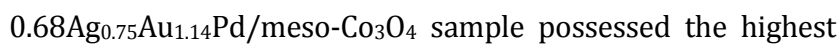
TOF noble metal as well as the highest methanol conversion and reaction rate, which might be a result due to the good dispersion of $\mathrm{Ag}_{0.75} \mathrm{Au}_{1.14} \mathrm{Pd}$ alloy NPs, high adsorbed oxygen species concentration, good low-temperature reducibility, and strong interaction between $\mathrm{Ag}_{0.75} \mathrm{Au}$ 1.14 Pd alloy NPs and meso-- $\mathrm{Co}_{3} \mathrm{O}_{4}$. The above results demonstrate that the alloying of $\mathrm{Pd}$ with proper amounts of $\mathrm{Ag}$ and $\mathrm{Au}$ favored the enhancement in methanol combustion activity of the sample.

There have been several works on the oxidation of methanol over various catalysts in the literature. Our 0.68 $\mathrm{Ag}_{0.75} \mathrm{Au}_{1.14} \mathrm{Pd} / \mathrm{meso}^{-\mathrm{Co}_{3} \mathrm{O}_{4}}$ sample showed a methanol reaction rate at $100{ }^{\circ} \mathrm{C}$ of $0.99 \mu \mathrm{mol} \mathrm{g}_{\mathrm{cat}^{-1}} \mathrm{~s}^{-1}$, which was higher than that $\left(0.01 \mu \mathrm{mol} \mathrm{g} \mathrm{cat}^{-1} \mathrm{~s}^{-1}\right)$ over meso- $\mathrm{Cr}_{2} \mathrm{O}_{3}$ [30], that $(0.03$ $\left.\mu \mathrm{mol} \mathrm{g} \mathrm{cat}^{-1} \mathrm{~s}^{-1}\right)$ over wormhole-like $\mathrm{Fe}_{2} \mathrm{O}_{3}$ [46], that $(0.11 \mu \mathrm{mol}$ $\left.\mathrm{gcat}^{-1} \mathrm{~s}^{-1}\right)$ over meso- $\mathrm{Co}_{3} \mathrm{O}_{4}$ [47], that $\left(0.60 \mu \mathrm{mol} \mathrm{g} \mathrm{cat}^{-1} \mathrm{~s}^{-1}\right)$ over $12 \mathrm{wt} \% \mathrm{MnO}_{x} / 3 \mathrm{DOM} \mathrm{LaMnO}_{3}$ [48], that $\left(0.45 \mu \mathrm{mol} \mathrm{g} \mathrm{gat}^{-1} \mathrm{~s}^{-1}\right)$ over $2 \mathrm{wt} \% \mathrm{Ag} / \mathrm{CeO}_{2}$ [49], and that $\left(0.88 \mu \mathrm{mol} \mathrm{g} \mathrm{gat}^{-1} \mathrm{~s}^{-1}\right)$ over $0.1 \mathrm{wt} \% \mathrm{Pd} / 5.0 \mathrm{wt} \% \mathrm{Ag} / 35 \mathrm{CZA}$ [50], but lower than that 3.50 $\mu \mathrm{mol} \mathrm{gat}{ }^{-1} \mathrm{~s}^{-1}$ ) over $0.8 \% \mathrm{Pd}-\mathrm{Pt} / \mathrm{CeO}_{2}-\mathrm{Al}_{2} \mathrm{O}_{3}-\mathrm{TiO}_{2}$ [14].

Considering a weak mobility of lattice oxygen in meso-- $\mathrm{Co}_{3} \mathrm{O}_{4}$ at low temperatures, methanol combustion over $\mathrm{Ag}_{x} \mathrm{Au}_{y} \mathrm{Pd} / \mathrm{meso}-\mathrm{Co}_{3} \mathrm{O}_{4}$ would hardly follow the Mars van Krevelen-type mechanism under the present reaction conditions. The interface mechanism could work well for methanol combustion over the reducible oxide-supported noble metal catalysts. Gas-phase oxygen was adsorbed on the surface oxygen vacancies of meso- $\mathrm{Co}_{3} \mathrm{O}_{4}$ to produce the active oxygen species, and methanol was adsorbed on the noble metal sites of the catalysts to form methoxy species that were easily oxidized to the formate species by the active oxygen species [49]; then, the generated formate species decomposed to CO and hydroxyl species; and finally, the formed CO was completely oxidized to $\mathrm{CO}_{2}$.

It is well known that catalytic activity is intimately associated with the transition-metal oxidation state, $\mathrm{O}_{\text {ads }}$ species concentration, and reducibility of a sample. The $\mathrm{O}_{\text {ads }} / \mathrm{O}_{\text {latt }}$ molar ratio versus surface $\mathrm{Co}^{3+} / \mathrm{Co}^{2+}$ molar ratio and methanol reaction rate at $100{ }^{\circ} \mathrm{C}$ versus $\mathrm{O}_{\text {ads }} / \mathrm{O}_{\text {latt }}$ molar ratio or initial $\mathrm{H}_{2}$ consumption rate of the samples are shown in Fig. 9. It can be observed that (i) the $\mathrm{O}_{\text {ads }} / \mathrm{O}_{\text {latt }}$ molar ratio increased with a drop in surface $\mathrm{Co}^{3+} / \mathrm{Co}^{2+}$ molar ratio (i.e., an increase in surface oxygen vacancy density that was induced by the strong interaction between noble metal NPs and meso- $\mathrm{Co}_{3} \mathrm{O}_{4}$ ) (Fig. 9A), (ii) methanol reaction rate increased with increasing the $\mathrm{O}_{\text {ads }} / \mathrm{O}_{\text {latt }}$ molar ratio (Fig. 9B), and (iii) methanol reaction rate 

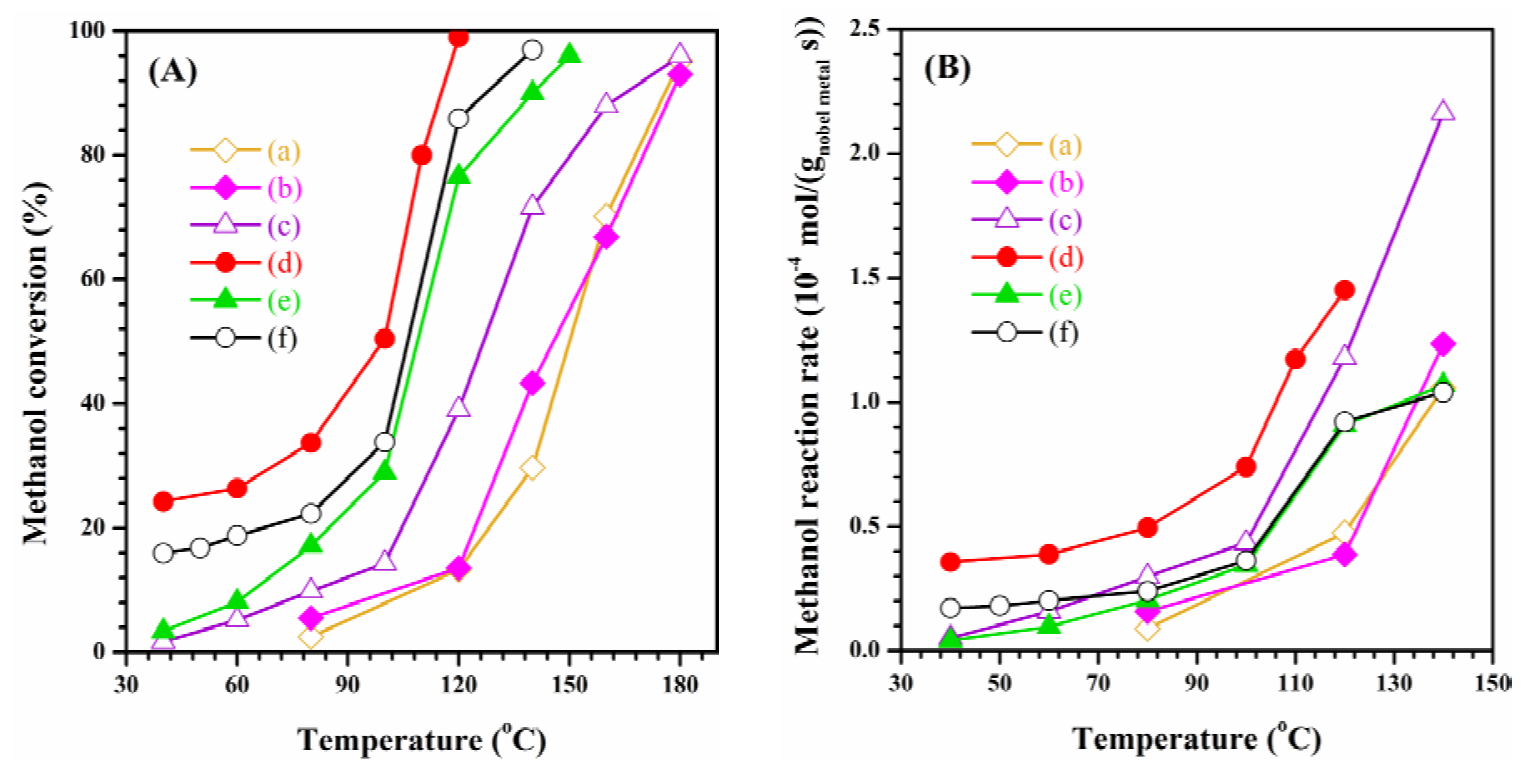

Fig. 8. (A) Methanol conversion and (B) reaction rate normalized per gram of noble metal versus temperature over (a) $0.28 \mathrm{Ag} / \mathrm{meso}^{-\mathrm{Co}} \mathrm{O}_{4},(\mathrm{~b})$

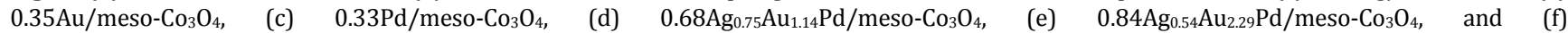

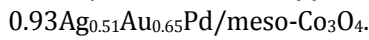
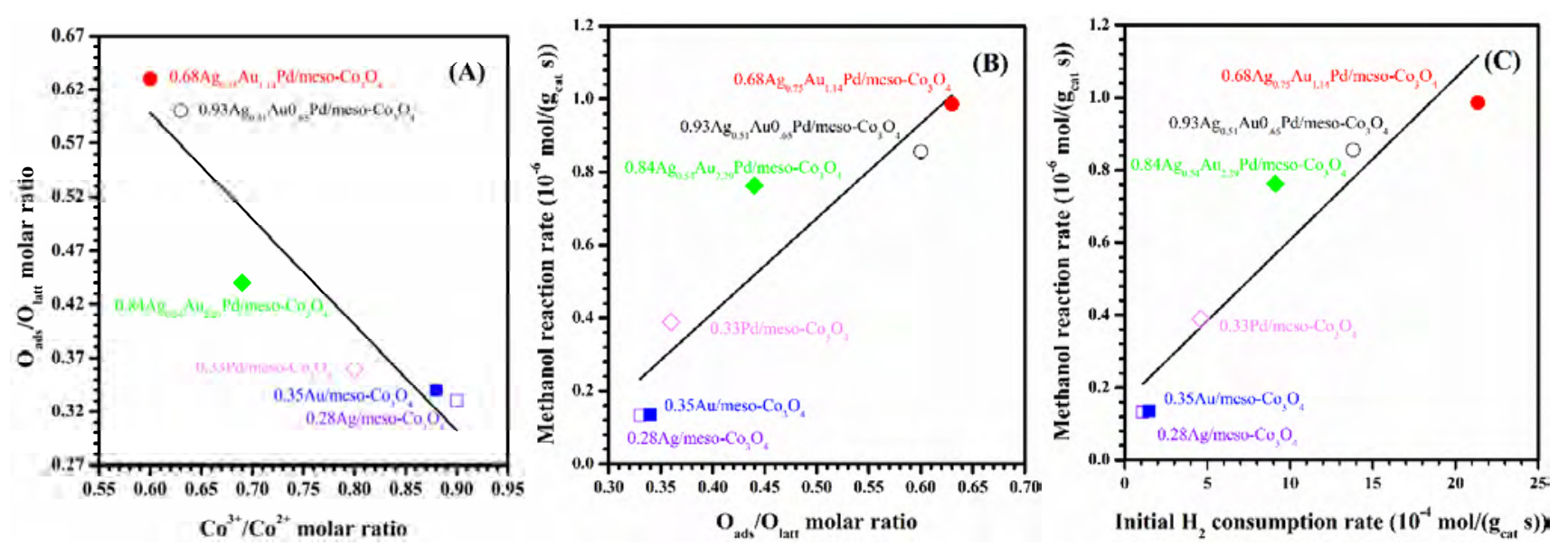

Fig. 9. (A) $\mathrm{O}_{\text {ads }} / \mathrm{O}_{\text {latt }}$ molar ratio versus surface $\mathrm{Co}^{3+} / \mathrm{Co}^{2+}$ molar ratio, (B) methanol reaction rate versus $\mathrm{O}_{\text {ads }} / \mathrm{O}_{\text {latt }}$ molar ratio, and (C) methanol reaction rate versus initial $\mathrm{H}_{2}$ consumption rate of the samples.

increased with an increase in initial $\mathrm{H}_{2}$ consumption rate (i.e., low-temperature reducibility) (Fig. 9C). Among all of the sam-

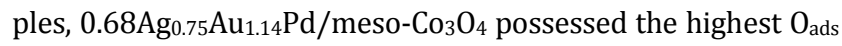
species concentration (the lowest $\mathrm{Co}^{3+} / \mathrm{Co}^{2+}$ molar ratio gave rise to the highest oxygen vacancy density) and the best low-temperature reducibility, hence showing the best catalytic performance for methanol combustion.

\subsection{Effect of water and carbon dioxide on activity}

Because water vapor exerted a negative effect on catalytic activity for the oxidation of VOCs [51], it is necessary to examine the effect of water vapor on catalytic activity of the typical sample. By introducing $3.0 \mathrm{vol} \%$ water vapor to the reaction system, we measured methanol conversions at $110{ }^{\circ} \mathrm{C}$ and $\mathrm{SV}=$ $80000 \mathrm{~mL} \mathrm{~g}^{-1} \mathrm{~h}^{-1}$ over the $0.68 \mathrm{Ag}_{0.75} \mathrm{Au}_{1.14} \mathrm{Pd} /$ meso- $^{-\mathrm{Co}_{3} \mathrm{O}_{4} \text { sam- }}$ ple, as shown in Fig. 10A. It is well known that water is easily adsorbed on the surface of noble metal (especially Pd) NPs. Obviously, methanol conversion dropped by ca. $6 \%$ after addition of 3.0 vol\% water vapor. When water vapor was cut off, methanol conversion was restored to its original value in the absence of water vapor, indicating that the partial deactivation induced by water vapor addition was reversible. Such a partial deactivation was due to the competitive adsorption of $\mathrm{H}_{2} \mathrm{O}$ and methanol as well as $\mathrm{O}_{2}$, leading to a decrease in catalytic activity $[52,53]$.

As one of the products of methanol combustion, $\mathrm{CO}_{2}$ might influence the activity of a catalyst. To examine the effect of $\mathrm{CO}_{2}$ on activity, we conducted methanol combustion at $110{ }^{\circ} \mathrm{C}$ and $\mathrm{SV}=80000 \mathrm{~mL} \mathrm{~g}^{-1} \mathrm{~h}^{-1}$ over $0.68 \mathrm{Ag}_{0.75} \mathrm{Au}_{1.14} \mathrm{Pd} / \mathrm{meso}-\mathrm{Co}_{3} \mathrm{O}_{4}$ in the presence of 5.0 vol\% $\mathrm{CO}_{2}$, and the results are shown in Fig. 10B. It is apparent that methanol conversion decreased by ca. $7 \%$ after $15 \mathrm{~h}$ of on-stream reaction. When $\mathrm{CO}_{2}$ was cut off, methanol conversion was recovered to its original value in the 

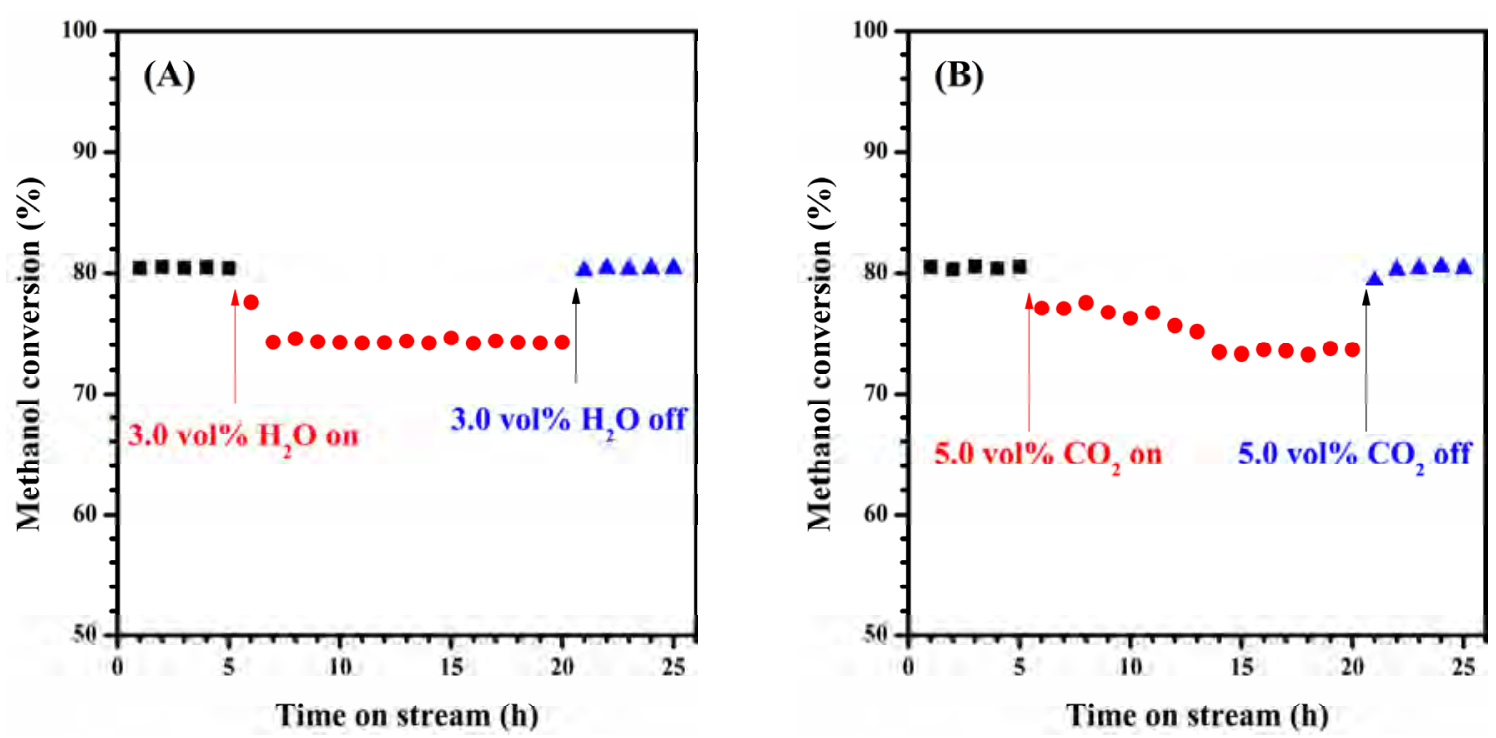

Fig. 10. Effects of (A) 3.0 vol $\% \mathrm{H}_{2} \mathrm{O}$ and (B) 5.0 vol\% $\mathrm{CO}_{2}$ on methanol oxidation over the $0.68 \mathrm{Ag}_{0.75} \mathrm{Au}_{1.14} \mathrm{Pd} / \mathrm{meso}^{-\mathrm{Co}} \mathrm{O}_{4} \mathrm{Sample}$ at $110{ }^{\circ} \mathrm{C}$ and $\mathrm{SV}=$ $80000 \mathrm{~mL} \mathrm{~g}^{-1} \mathrm{~h}^{-1}$.

absence of carbon dioxide. $\mathrm{CO}_{2}$ molecules were adsorbed on the active sites of the sample to form the $\mathrm{CO}_{3}{ }^{2-}$ or $\mathrm{HCO}_{3}{ }^{-}$species, thus influencing the activity. After $\mathrm{CO}_{2}$ was cut off, however, these carbonate species were possibly desorbed from the active sites of the sample, hence recovering the occupied active sites.

\section{Conclusions}

The cubically crystallized meso- $\mathrm{Co}_{3} \mathrm{O}_{4}$ and its supported $\mathrm{Ag}_{x} \mathrm{Au}_{y} \mathrm{Pd}, \mathrm{Ag}, \mathrm{Au}$, and $\mathrm{Pd}$ catalysts were prepared using the KIT-6-templating and PVA-protected $\mathrm{NaBH}_{4}$ reduction methods, respectively. The as-obtained materials displayed a three-dimensionally ordered mesoporous structure and a high surface area (115-125 $\mathrm{m}^{2} / \mathrm{g}$ ), and the noble metal NPs with an average size of $2.8-4.5 \mathrm{~nm}$ were highly dispersed on the surface of meso- $\mathrm{Co}_{3} \mathrm{O}_{4}$. The supported $\mathrm{Ag}_{x} \mathrm{Au}_{y} \mathrm{Pd}$ samples outperformed the $\mathrm{Ag}$, $\mathrm{Au}$ or $\mathrm{Pd}$ sample, with the

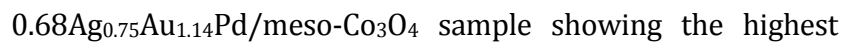
catalytic activity $\left(T_{50 \%}=100{ }^{\circ} \mathrm{C}\right.$ and $T_{90 \%}=112{ }^{\circ} \mathrm{C}$ at $\mathrm{SV}=$ $80000 \mathrm{~mL} \mathrm{~g}^{-1} \mathrm{~h}^{-1}$ ) for methanol combustion. The partial deactivation due to $\mathrm{H}_{2} \mathrm{O}$ or $\mathrm{CO}_{2}$ addition of the 0.68 $\mathrm{Ag}_{0.75} \mathrm{Au}_{1.14} \mathrm{Pd} / \mathrm{meso}^{-\mathrm{Co}_{3} \mathrm{O}_{4}}$ sample was reversible. It is concluded that the good catalytic performance of $0.68 \mathrm{Ag}_{0.75} \mathrm{Au}_{1.14} \mathrm{Pd} / \mathrm{meso}-\mathrm{Co}_{3} \mathrm{O}_{4}$ was related to the highly dispersed $\mathrm{Ag}_{0.75} \mathrm{Au}_{1.14} \mathrm{Pd}$ alloy NPs, high $\mathrm{O}_{\text {ads }}$ species concentration, good low-temperature reducibility, and strong interaction between $\mathrm{Ag}_{0.75} \mathrm{Au}_{1.14} \mathrm{Pd}$ alloy NPs and meso- $\mathrm{Co}_{3} \mathrm{O}_{4}$.

\section{References}

[1] L. A. Calzada, S. E. Collins, C. W. Han, V. Ortalan, R. Zanella, Appl. Catal. B, 2017, 207, 79-92.

[2] N. G. Patel, P. D. Patel, V. S. Vaishnav, Sens. Actuat. B, 2003, 96, 180-189.

[3] A. Mirzaei, S. G. Leonardi, G. Neri, Ceram. Int., 2016, 42, 15119-15141.
[4] W. L. Wang, Q. J. Meng, Y. H. Xue, X. L. Weng, P. F. Sun, Z. B. Wu, J. Catal., 2018, 366, 213-222.

[5] S. C. Kim, W. G. Shim, Appl. Catal. B, 2009, 92, 429-436.

[6] F. J. Maldonado-Hódar, C. Moreno-Castilla, A. F. Pérez-Cadenas, Appl. Catal. B, 2004, 54, 217-224.

[7] A. M. Sica, J. H. Z. D. Santos, I. M. Baibich, C. E. Gigola, J. Mol. Catal. A, 1999, 137, 287-295.

[8] K. Persson, L. D. Pfefferle, W. Schwartz, A. Ersson, S. G. Jaras, Appl. Catal. B, 2007, 74, 242-250.

[9] J. Q. Jiao, Y. C. Wei, Y. L. Zhao, Z. Zhao, A. J. Duan, J. Liu, Y. Y. Pang, J. M. Li, G. Y. Jiang, Y. J. Wang, Appl. Catal. B, 2017, 209, 228-239.

[10] Y. C. Wei, X. X. Wu, Y. L. Zhao, L. Wang, Z. Zhao, X. T. Huang, J. Liu, J. M. Li, Appl. Catal. B, 2018, 236, 445-457.

[11] J. Xiong, Q. Q. Wu, X. L. Mei, J. Liu, Y. C. Wei, Z. Zhao, D. Wu, J. M. Li, ACS Catal., 2018, 8, 7915-7930.

[12] Z. W. Wang, Y. X. Liu, T. Yang, J. G. Deng, S. H. Xie, H. X. Dai, Chin. J. Catal., 2017, 38, 207-216.

[13] S. H. Xie, J. G. Deng, S. M. Zang, H. G. Yang, G. S. Guo, H. Arandiyan, H. X. Dai, J. Catal., 2015, 322, 38-48.

[14] Y. Y. Guo, S. Zhang, J. Zhu, L. Q. Su, X. M. Xie, Z. Li, Appl. Surf. Sci,, 2017, 416, 358-364.

[15] S. H. Xie, Y. X. Liu, J. G. Deng, S. M. Zang, Z. H. Zhang, H. Arandiyan, H. X. Dai, Environ. Sci. Technol., 2017, 51, 2271-2279.

[16] H. J. Sedjame, C. Fontaine, G. Lafaye, J. Barbier Jr., Appl. Catal. B, 2014, 144, 233-242.

[17] B. Rivas, J. I. Gutierrez-Ortiz, R. Lopez-Fonseca, J. R. Gonzalez-Velasco, Appl. Catal. A, 2006, 314, 54-63.

[18] K. Okumura, T. Kobayashi, H. Tanaka, M. Niwa, Appl. Catal. B, 2003, 44, 325-331.

[19] Y. Ren, Z. Ma, P. G. Bruce, Chem. Soc. Rev., 2012, 41, 4909-4927.

[20] D. Gu, F. Schüth, Chem. Soc. Rev., 2014, 43, 313-344.

[21] Y. F. Wang, C. B. Zhang, F. D. Liu, H. He, Appl. Catal. B, 2013, $142-143,72-79$.

[22] X. M. Zhang, Y. Q. Deng, P. F. Tian, H. H. Shang, J. Xu, Y. F. Han, Appl. Catal. B, 2016, 191, 179-191.

[23] B. Y. Bai, J. H. Li, J. M. Hao, Appl. Catal. B, 2015, 164, 241-250.

[24] Q. Liu, L. C. Wang, M. Chen, Y. Cao, H. Y. He, K. N. Fan, J. Catal., 2009, 263, 104-113.

[25] Z. X. Wu, J. G. Deng, Y. X. Liu, S. H. Xie, Y. Jiang, X. T. Zhao, J. Yang, H. 


\section{Graphical Abstract}

Chin. J. Catal., 2019, 40: 837-848 doi: 10.1016/S1872-2067(18)63205-X

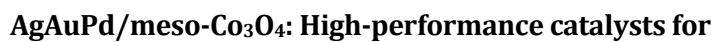 methanol oxidation}

Jun Yang, Yuxi Liu *, Jiguang Deng, Xingtian Zhao, Kunfeng Zhang, Zhuo Han, Hongxing Dai *

Beijing University of Technology

$\mathrm{Ag}_{x} \mathrm{Au}_{y} \mathrm{Pd} / \mathrm{meso}-\mathrm{Co}_{3} \mathrm{O}_{4}$ catalysts are prepared using the KIT-6-templating and PVA-protected reduction methods. The good catalytic activity of $0.68 \mathrm{wt} \% \mathrm{Ag}_{0.75} \mathrm{Au}_{1.14} \mathrm{Pd} / \mathrm{meso}-\mathrm{Co}_{3} \mathrm{O}_{4}$ for methanol combustion is associated with its highly dispersed $\mathrm{Ag}_{0.75} \mathrm{Au}_{1.14} \mathrm{Pd}$ alloy nanoparticles (NPs), high $\mathrm{O}_{\text {ads }}$ species concentration, good low-temperature reducibility, and strong interaction between noble metal NPs and meso- $\mathrm{Co}_{3} \mathrm{O}_{4}$.

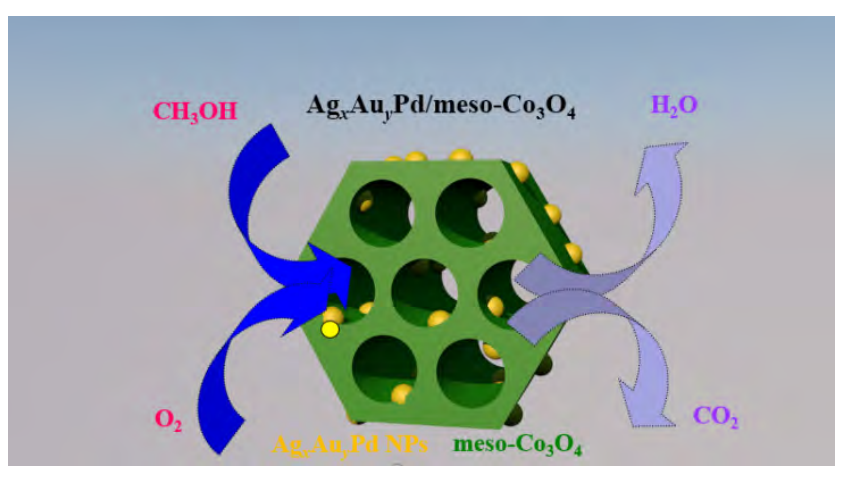

Arandiyan, G. S. Guo, H. X. Dai, J. Catal., 2015, 332, 13-24.

[26] Y. X. Liu, H. X. Dai, J. G. Deng, S. H. Xie, H. G. Yang, W. Tan, W. Han, Y. Jiang, G. S. Guo, J. Catal., 2014, 309, 408-418.

[27] Z. X. Wu, J. G. Deng, S. H. Xie, H. G. Yang, X. T. Zhao, K. F. Zhang, H. X. Lin, H. X. Dai, G. S. Guo, Microporous Mesoporous Mater., 2016, 224, 311-322.

[28] P. Xu, Z. X. Wu, J. G. Deng, Y. X. Liu, S. H. Xie, G. S. Guo, H. X. Dai, Chin. J. Catal., 2017, 38, 92-105.

[29] Y. S. Xia, H. X. Dai, H. Y. Jiang, J. G. Deng, H. He, C. T. Au, Environ. Sci. Technol., 2009, 43, 8355-8360.

[30] Y. S. Xia, H. X. Dai, L. Zhang, J. G. Deng, H. He, C. T. Au, Appl. Catal. B, 2010, 100, 229-237.

[31] F. Kleitz, S. H. Choi, R. Ryoo, Chem. Commun., 2003, 2136-2137.

[32] X. C. Zhang, J. Wang, L. C. Xuan, Z. B. Zhu, Q. J. Pan, K. Y. Shi, G. Zhang, J. Alloys Compd., 2018, 768, 190-197.

[33] S. Dubey, J. Kumar, A. Kumar, Y. C. Sharma, Adv. Powder Technol., 2018, 29, 2583-2590.

[34] S. R. Naik, A. V. Salker, S. M. Yusuf, S. S. Meena, J. Alloys Compd., 2013, 566, 54-61.

[35] C. V. Schenck, J. G. Dillard, J. W. Murray, J. Colloid Interface Sci., 1983, 95, 398-409.

[36] G. J. Zhang, Y. E. Wang, X. Wang, Y. Chen, Y. M. Zhou, Y. W. Tang, L. D. Lu, J. C. Bao, T. H. Lu, Appl. Catal. B, 2011, 102, 614-619.

[37] G. Corro, E. Vidal, S. Cebada, U. Pal, F. Banuelos, D. Vargas, E. Guilleminot, Appl. Catal. B, 2017, 216, 1-10.

[38] X. She, M. Flytzani-Stephanopoulos, J. Catal., 2006, 237, 79-93.

[39] A. K. Sinha, K. Suzuki, M. Takahara, H. Azuma, T. Nonaka, K. Fukumoto, Angew. Chem. Int. Ed., 2007, 46, 2891-2894.

[40] K. R. Priolkar, P. Bera, P. R. Sarode, M. S. Hegde, S. Emura, R. Ku- mashiro, N. P. Lalla, Chem. Mater., 2002, 14, 2120-2128.

[41] H. Gabasch, K. Hayek, B. Klo1tzer, W. Unterberger, E. Kleimenov, D. Teschner, S. Zafeiratos, M. Halvecker, A. Knop-Gericke, R. Schlolg, B. Aszalos-Kiss, D. Zemlyanov, J. Phys. Chem. C, 2007, 111, 7957-7962.

[42] A. R. Belambe, R. Oukaci, J. G. Goodwin Jr., J. Catal., 1997, 166, 8-15.

[43] B. Solsona, T. E. Davies, T. Garcia, I. Vazquez, A. Dejoz, S. H. Taylor, Appl. Catal. B, 2008, 84, 176-184.

[44] K. D. Chen, S. B. Xie, A. T. Bell, E. Iglesia, J. Catal., 2001, 198, 232-242.

[45] H. X. Dai, A. T. Bell, E. Iglesia, J. Catal., 2004, 221, 491-499.

[46] Y. S. Xia, H. X. Dai, H. Y. Jiang, L. Zhang, J. G. Deng, Y. X. Liu, J. Hazard. Mater., 2011, 186, 84-91.

[47] Y. S. Xia, H. X. Dai, H. Y. Jiang, L. Zhang, Catal. Commun., 2010, 11, 1171-1175.

[48] Y. X. Liu, H. X. Dai, J. G. Deng, Y. C. Du, X. W. Li, Z. X. Zhao, Y. Wang, B. Z. Gao, H. G. Yang, Appl. Catal. B, 2013, 140-141, 493-505.

[49] N. Shimoda, S. Umehara, M. Kasahara, T. Hongoa, A. Yamazaki, S. Satokaw, Appl. Catal. A, 2015, 507, 56-64.

[50] Y. J. Luo, Y. H. Xiao, G. H. Cai, Y. Zheng, K. M. Wei, Fuel, 2012, 93, 533-538.

[51] S. H. Xie, H. X. Dai, J. G. Deng, Y. X. Liu, H. G. Yang, Y. Jiang, W. Tan, A. S. Ao, G. S. Guo, Nanoscale, 2013, 5, 11207-11219.

[52] S. H. Xie, Y. X. Liu, J. G. Deng, X. T. Zhao, J. Yang, K. F. Zhang, Z. Han, H. Arandiyan, H. X. Dai, Appl. Catal. B, 2017, 206, 221-232.

[53] X. Y. Li, Y. X. Liu, J. G. Deng, S. H. Xie, X. T. Zhao, Y. Zhang, K. F. Zhang, H. Arandiyan, G. S. Guo, H. X. Dai, Appl. Surf. Sci., 2017, 403, 590-600.

\section{AgAuPd/meso- $\mathrm{Co}_{3} \mathrm{O}_{4}$ 高效甲醇氧化催化剂}

杨 军, 刘雨溪, 邓积光, 赵星天, 张昆锋, 韩 卓, 戴洪兴 ${ }^{*}$

北京工业大学环境与能源工程学院化学化工系, 绿色催化与分离北京市重点实验室, 区域大气复合污染防治北京市重点实验室, 先进功能材料教育部重点实验室, 催化化学与纳米科学实验室, 北京 100124

摘要: 甲醇是重要的化工原料和溶剂, 也是一种典型的挥发性有机物(VOCs), 其排放会对人体和大气环境造成危害. 迄今 为止, 最有效的消除低浓度VOCs的方法是催化氧化. 该方法具有VOCs去除效率高、起燃温度低、设备简单且无二次污染 等优点. 众所周知, 负载贵金属催化剂对VOCs氧化显示良好的低温活性, 但反应气流中的水分会降低贵金属的催化性能. 
研究表明, 与单一贵金属催化剂相比, 贵金属合金催化剂不仅具有高的催化活性, 而且还具有良好的水热稳定性. 尽管已 有文献报道了二元贵金属合金催化剂对VOCs的催化氧化, 然而VOCs在三元贵金属合金上催化氧化的研究则较少. 本文 采用三维有序介孔结构的二氧化硅(KIT-6)硬模板法和聚乙烯醇保护的嗍氢化钠还原法制备了 $0.68 \mathrm{wt} \%$

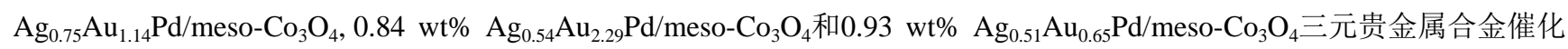
剂以及 $0.28 \mathrm{wt} \% \mathrm{Ag} / \mathrm{meso}-\mathrm{Co}_{3} \mathrm{O}_{4}, 0.35 \mathrm{wt} \% \mathrm{Au} / \mathrm{meso}^{-} \mathrm{Co}_{3} \mathrm{O}_{4}$ 和 $0.33 \mathrm{wt} \% \mathrm{Pd} / \mathrm{meso}^{-} \mathrm{Co}_{3} \mathrm{O}_{4}$ 单一贵金属催化剂. 利用电感耦合等 离子体-原子发射光谱(ICP-AES)、X射线衍射(XRD)、透射电子显微镜(TEM)、高角环形暗场-扫描透射电子显微镜 (HAADF-STEM)、X射线光电子能谱(XPS)和氢气-程序升温还原 $\left(\mathrm{H}_{2}-\mathrm{TPR}\right)$ 技术表征了催化剂的物化性质. 催化剂的活性评 价在固定床石英微型反应器中进行, 反应气组成为 $0.1 \%$ 甲醇 + 氧气 + 氮气(平衡气), 甲醇 $/$ 氧气摩尔比为 $1 / 200$, 空速约 为 $80000 \mathrm{~mL} \mathrm{~g}^{-1} \mathrm{~h}^{-1}$, 利用气相色谱检测反应物和产物的浓度.

广角度XRD结果表明, meso- $\mathrm{Co}_{3} \mathrm{O}_{4}$ 具有立方晶相结构. XRD谱中未检测到 $\mathrm{Ag}, \mathrm{Au}$ 和Pd的衍射峰, 系贵金属负载量低且 均匀分散在载体表面所致. 贵金属粒径为 $2.8-4.5 \mathrm{~nm}$. 小角度 XRD和TEM结果表明, meso- $\mathrm{Co}_{3} \mathrm{O}_{4}$ 具有有序介孔结构. 从 HAADF-STEM照片可以观察到, $0.68 \mathrm{wt} \% \mathrm{Ag}_{0.75} \mathrm{Au}_{1.14} \mathrm{Pd} / \mathrm{meso}-\mathrm{Co}_{3} \mathrm{O}_{4}$ 中的贵金属形成了 Ag-Au-Pd合金. BET结果显示, 所 制得催化剂的比表面积为 $115-120 \mathrm{~m}^{2} / \mathrm{g}$, 孔径为 $5.7-6.0 \mathrm{~nm}$, 孔容为 $0.15-0.16 \mathrm{~cm}^{3} / \mathrm{g}$. XPS结果表明, 贵金属与载体之间较强 的相互作用使 $0.68 \mathrm{wt} \% \mathrm{Ag}_{0.75} \mathrm{Au}_{1.14} \mathrm{Pd} / \mathrm{meso}^{-} \mathrm{Co}_{3} \mathrm{O}_{4}$ 具有最低的表面 $\mathrm{Co}^{3+} / \mathrm{Co}^{2+}$ 摩尔比, 从而使该催化剂表面拥有更多的氧空 位, 有利于吸附和活化氧气, 提高表面吸附氧浓度, 从而提高催化活性. $0.68 \mathrm{wt} \% \mathrm{Ag}_{0.75} \mathrm{Au}_{1.14} \mathrm{Pd} / \mathrm{meso}-\mathrm{Co}_{3} \mathrm{O}_{4}$ 具有最低的还 原温度(即最好的低温还原性), 有利于催化活性的提高. 因此, 高分散的 $\mathrm{Ag}_{0.75} \mathrm{Au}_{1.14} \mathrm{Pd}$ 纳米粒子、高的吸附氧浓度、优良的 低温还原性以及载体与 $\mathrm{Ag}_{0.75} \mathrm{Au}_{1.14} \mathrm{Pd}$ 粒子之间强的相互作用是 $0.68 \mathrm{Ag}_{0.75} \mathrm{Au}_{1.14} \mathrm{Pd} / \mathrm{meso}-\mathrm{Co}_{3} \mathrm{O}_{4}$ 具有最高催化活性(当空速为 $80000 \mathrm{~mL} \mathrm{~g}^{-1} \mathrm{~h}^{-1}$ 时, $T_{50 \%}=100{ }^{\circ} \mathrm{C}$ 和 $T_{90 \%}=112{ }^{\circ} \mathrm{C}$ )的主要原因. 在反应温度为 $110{ }^{\circ} \mathrm{C}$ 和空速为 $80000 \mathrm{~mL} \mathrm{~g}^{-1} \mathrm{~h}^{-1}$ 的条件下, 向 反应体系中分别引入 $3.0 \mathrm{vol} \%$ 水蒸气和 $5.0 \mathrm{vol} \%$ 二氧化碳, 甲醇转化率分别下降 $6.0 \%$ 和 $7.0 \%$; 当切断水和二氧化碳后, 甲醇 转化率均恢复到在无水和二氧化碳时的数值. 因此, 水和二氧化碳对该催化剂的失活是可逆的. 换句话说, $0.68 \mathrm{wt} \%$ $\mathrm{Ag}_{0.75} \mathrm{Au}_{1.14} \mathrm{Pd} / \mathrm{meso}-\mathrm{Co}_{3} \mathrm{O}_{4}$ 具有优良的水热稳定性和抗二氧化碳中毒能力.

关键词: 挥发性有机物; 介孔四氧化三钴; 负载贵金属催化剂; AgAuPd合金纳米粒子; 甲醇氧化

收稿日期: 2018-10-27. 接受日期: 2018-11-26. 出版日期: 2019-06-05.

*通讯联系人. 电话: (010)67396118; 传真: (010)67391983; 电子信箱: yxliu@bjut.edu.cn

通讯联系人. 电话: (010)67396118; 传真: (010)67391983; 电子信箱: hxdai@bjut.edu.cn 基金来源：国家自然科学基金(21677004, 21876006, 21622701); 国家高技术研究发展计划(863计划, 2015AA034603). 本文的电子版全文由Elsevier出版社在ScienceDirect上出版(http://www.sciencedirect.com/science/journal/18722067). 